\title{
Earliest Evidence for the Ivory Trade in Southern Africa: Isotopic and ZooMS Analysis of Seventh-Tenth Century AD Ivory from KwaZulu-Natal
}

\author{
Ashley N. Coutu • Gavin Whitelaw • Petrus le Roux • \\ Judith Sealy
}

Published online: 1 October 2016

(C) The Author(s) 2016. This article is published with open access at Springerlink.com

\begin{abstract}
KwaGandaganda, Ndondondwane and Wosi were major Early Farming Community settlements in what is today the KwaZulu-Natal province of South Africa. These sites have yielded, among other remains, abundant evidence of ivory and ivory working dating to the seventh-tenth centuries $\mathrm{AD}$, pre-dating by approximately 200 years the better-known ivory artefacts from sites in the Limpopo River Valley and surrounding regions. We report the results of carbon, nitrogen and
\end{abstract}

Time period: Early Iron Age

Country and region discussed: South Africa, KwaZulu-Natal

Electronic supplementary material The online version of this article (doi:10.1007/s10437-016-9232-0) contains supplementary material, which is available to authorized users.

A. N. Coutu $(\bowtie) \cdot$ J. Sealy

Department of Archaeology, University of Cape Town, Private

Bag X3, Rondebosch 7701, South Africa

e-mail: ashley.coutu@uct.ac.za

A. N. Coutu

BioArCh, Department of Archaeology, University of York,

York YO10 5DD, UK

G. Whitelaw

KwaZulu-Natal Museum, Private Bag 9070,

Pietermaritzburg 3200, South Africa

G. Whitelaw

School of Social Sciences, University of KwaZulu-Natal, Private

Bag X54001, Durban 4000, South Africa

P. le Roux

Department of Geological Sciences, University of Cape Town,

Private Bag X3, Rondebosch 7701, South Africa strontium isotope analysis to explore the origins and procurement of this ivory, in combination with Zooarchaeology by Mass Spectrometry (ZooMS) to identify the species of animals from which it was derived. All of the ivory studied using ZooMS was elephant, despite the presence of hippopotamus remains on all three sites. Some ivory was probably obtained from elephant herds that lived close to the sites, in the densely wooded river valleys favoured by both elephants and early farmers. Other material came from savannah environments further afield. Ivory found at these three sites was drawn from different catchments, implying a degree of landscape/resource partitioning even at this early stage. These communities clearly invested substantial effort in obtaining ivory from across the region, which speaks to the importance of this commodity in the economy of the time. We suggest that some ivory items were for local use, but that some may have been intended for more distant markets via Indian Ocean trade.

Résumé Les sites de KwaGandaganda, Ndondondwane et Wosi ont été des peuplements majeurs de communautés d'agriculteurs précoces dans ce qui est. aujourd'hui la province de KwaZulu-Natal, en Afrique du Sud. Ces sites ont donné, parmi d'autres vestiges, des preuves abondantes d'ivoire et d'ivoire travaillé datant des siècles VIIe à Xe de notre ère, ce qui précéde, par environ 200 ans, des artéfacts d'ivoire mieux connus provenants de sites de la vallée du Limpopo et des régions environnantes. Ici nous rapportons des résultats d'analyses d'isotopes de carbone, d'azote et de strontium, en combinaison avec de la zooarchéologie par 
spectrométrie de masse (ZooMS) pour identifier les espèces d'animaux à partir de lesquelles l'ivoire archéologique a dérivé, et aussi pour explorer ses origines et ses marchés. Tout l'ivoire étudié en utilisant de la ZooMS a dérivé d'éléphant, malgré la présence de vestiges d'hippopotame sur les trois sites. Une partie de cet ivoire a probablement été obtenu à partir des troupeaux d'éléphants qui vivaient près des sites dans les vallées densément boisées qui étaient les favoris des éléphants aussi bien que ceux des agriculteurs précoces. D'autre matériel est. provenu de milieux de savane plus éloignés. L'ivoire trouvé aux trois sites est., donc, provenu de différents bassins versants, ce qui implique un certain degré de partitionnement de la paysage et des ressources, même à ce stade précoce. Ces communautés ont clairement investi des efforts considérables dans l'obtention de l'ivoire de toute la région, ce qui témoigne l'importance de cette denrée dans l'économie de cette époque. Nous suggérons que certains articles manufacturés de l'ivoire étaient probablement à l'usage local, mais que d'autres peuvent avoir été destinés à des marchés plus éloignés via le commerce de l'océan Indien.

Keywords Elephant · Carbon · Nitrogen · Strontium . Early Farming Community Early Iron Age

\section{Introduction}

In this paper, we report on the earliest and most southerly evidence for ivory trade in precolonial Africa. The sites of KwaGandaganda, Ndondondwane and Wosi in the South African province of KwaZulu-Natal (Fig. 1) have yielded large quantities of waste chips from ivory working (Fig. 2) and a number of (mostly fragmentary) ivory artefacts (Figs. 3 and 4). This evidence dates from the Msuluzi and Ndondondwane phases of the Early Iron Age sequence, c. seventh-tenth centuries AD. Ivory seems surprisingly abundant, so an intriguing question is the destination of this material. Overlapping with the later part of this time period, we see similar evidence of ivory working at the site of Schroda (tenth-eleventh centuries AD) further to the north in the Limpopo River Valley, and thereafter at K2, close to Mapungubwe Hill (Hanisch 1980, 1981; Raath 2014; Voigt 1983). The Limpopo River Valley is well known to have been part of a trans-Indian Ocean trade network, exporting local products that likely included ivory in exchange for glass beads, glazed ceramics and other luxury goods. How and where did trans-oceanic trade to and from southern Africa first begin? Was ivory from KwaZulu-Natal linked to such a network, several centuries earlier?

Here, we try to gain a better understanding of patterns of ivory procurement by analysing the stable carbon $\left({ }^{13} \mathrm{C} /{ }^{12} \mathrm{C}\right)$ and nitrogen $\left({ }^{15} \mathrm{~N} /{ }^{14} \mathrm{~N}\right)$ isotope compo sition of archaeological ivory from the sites of KwaGandaganda, Ndondondwane and Wosi, together with strontium isotopes $\left({ }^{87} \mathrm{Sr} /{ }^{86} \mathrm{Sr}\right)$. Carbon and nitrogen isotopes reflect the diets the elephants consumed, informing us about the habitats in which they lived and thus the likely catchment of this material. Strontium isotopes reflect the geological substrates on which the animals lived. Did the ivory derive from local elephant populations, or was it sourced from further afield, presumably in response to greater demand? Did Early Iron Age communities use ivory from hippopotamus (Hippopotamus amphibius) and/or warthog (Phacochoerus africanus), as well as elephant (Loxodonta africana)? Zooarchaeology by Mass Spectrometry (ZooMS) enables us to identify even very small fragments of ivory to species. Here, we present the first such analyses in southern African archaeology.

\section{Early Farmers in KwaZulu-Natal}

The first farmers arrived in KwaZulu-Natal c. AD 400 as part of an expansion southwards from East Africa through the eastern coastal regions of the subcontinent (Huffman 2007, pp. 331-359; Phillipson 1977; Russell et al. 2014). Links with East Africa are attested by remarkable similarities between the earliest South African ceramics and Kwale ware from Kenya and Tanzania (Huffman 2007, p. 122; Maggs 1980). These communities brought with them domesticated cattle and small stock, as well as crops such as sorghum and millet. These are tropical grains adapted to summer rainfall conditions, so farming communities settled in the northern and eastern parts of South Africa, where it is possible to grow these crops without irrigation. These groups also brought knowledge of iron smelting and iron working and were the first societies in South Africa to live in settled villages.

The chronological sequence of early farming communities in KwaZulu-Natal is based on the identification of sequential ceramic assemblages, tightly anchored in a series of radiocarbon dates. The earliest phase is called Mzonjani (AD 400-600), followed by Msuluzi 
Fig. 1 Upper map shows location of wildlife reserves (black dots) with modern elephant populations that yielded the published ivory isotope data referenced in Fig. 10. White dots indicate locations of

archaeological sites in KwaZuluNatal (KwaGandaganda, Wosi and Ndondondwane - the latter two incorporated into one white $d o t$ at this scale). Base map of vegetation cover from GlobCover (C) European Space Agency 2010 and UCLouvain (GlobCover 2008). Lower map is shaded by vegetation bioregions according to Mucina and Rutherford (2006) with white dots indicating locations of archaeological sites mentioned in the text $(K w a$

KwaGandaganda, Wos Wosi, Ndo Ndondondwane, Msu Msuluzi Confluence, Mag Magogo, Mhl Mhlopeni). Dark shading to the west of the sites represents subescarpment grassland (dark green in online version), lighter shading where the sites are located represents sub-escarpment savanna, shading northeast of the sites where Ulundi is located represents lowveld savanna (blue in online version) and shading where Durban is located represents the Indian Ocean coastal belt (brown in online version)
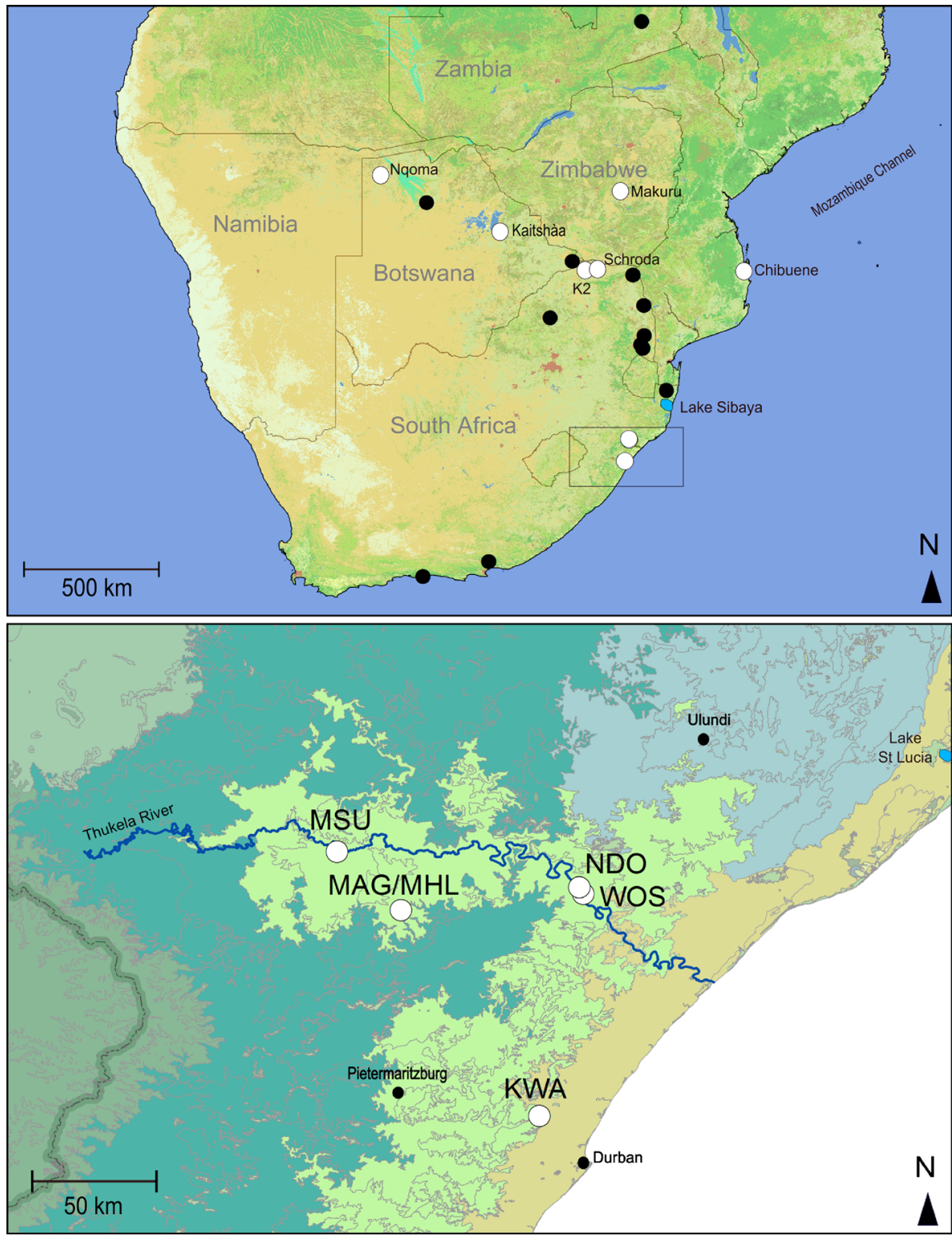

(650-780), Ndondondwane (780-910) and Ntshekane (910-1030), each named for the site at which it was first identified (Whitelaw 2013).

The few Mzonjani phase sites are found near the coast. From the Msuluzi phase onwards, settlements were located mainly within river valleys which provided deep, fertile soils for agriculture and ready access to water. These habitats would also have been prime elephant territory. Models of historic African elephant densities have shown that, prior to large-scale human encroachment, densities were positively correlated with high mean annual precipitation, and related ecological variables such as biomass productivity (de Boer et al. 2013). In KwaZulu-Natal, high-resolution diatom records from Lake Sibaya (Fig. 1) indicate that conditions between $\mathrm{AD} 750$ and 1000 were generally wetter than today, with a marked spike in rainfall between $\mathrm{AD} 790$ and 830 (Stager et al. 2013). Vegetation in the deeply incised river valleys occupied by Early Farming Communities was denser than it is currently. Remains of nyala antelope (Tragelaphus angasi) at several sites in the Thukela Basin provide one proxy for environmental conditions during the second half of the first millennium (Maggs and Michael 1976; Voigt 1984). Nyala live in 
Fig. 2 Ivory working waste from

KwaGandaganda, Square 22

midden, Level 2 (photo-A.

Coutu)

dense bush and thicket. Today, the nearest suitable habitat occurs in northern KwaZulu-Natal. The archaeological evidence shows that during the Early Iron Age, the Thukela and other river valleys to the north were sufficiently densely vegetated to support nyala and other bush-loving species. A combination of climate change and bush clearance by early farming communities subsequently led to the extirpation of nyala at the southern end of its range. These river valleys would have supported populations of elephants that came into increasing contact with humans as settlements became larger and agricultural production grew from the Msuluzi phase (seventh c. AD) onwards. Contact and conflict between elephants and farmers in more recent times are well documented, as both seek out areas with productive soils and permanent water sources (Balfour et al. 2007; O'Connell-Rodwell et al. 2000; Sitati et al. 2005; Stone 1972).

In the next section, we summarise relevant aspects of the archaeology of the sites of Ndondondwane,

Fig. 3 Ivory armband found at KwaGandaganda in the red crust (burnt layer) of Grid 4, dating to the Ndondondwane phase. The armband was approximately $9.5 \mathrm{~cm}$ in diameter, $4.5 \mathrm{~cm}$ tall and a maximum of $1 \mathrm{~cm}$ thick (UCT lab no 14415 ; KZN no 22) (photo-A. Coutu)

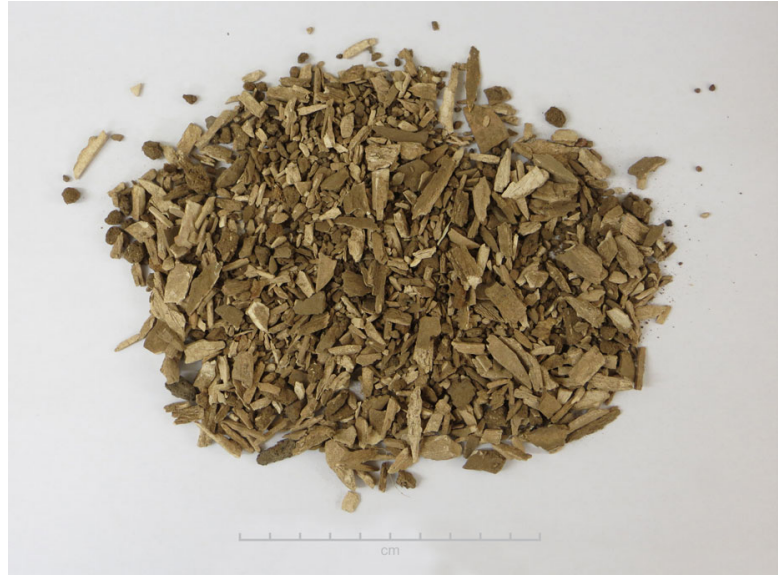

KwaGandaganda and Wosi, from which we obtained the ivory samples analysed in this study.

\section{Ndondondwane}

Excavations at Ndondondwane were initiated by Maggs (1984b) in 1978, followed by a second phase in 19821983 (Loubser 1993) and third phase beginning in 1995 (Greenfield and Van Schalkwyk 2003). Excavations into a low mound (Fig. 5) yielded a large quantity of cultural material and food waste, as well as abundant evidence of iron smelting and ivory working together with pottery, fragments of ceramic sculpture and other finds. At the base of the mound, the excavation revealed channels and post-holes, interpreted as the base of stockades supported by poles and filled in with reeds or branches (Loubser 1993; Maggs 1984b). This stockade may have served to screen off a special activity area where people worked iron and/or ivory, or it may simply have

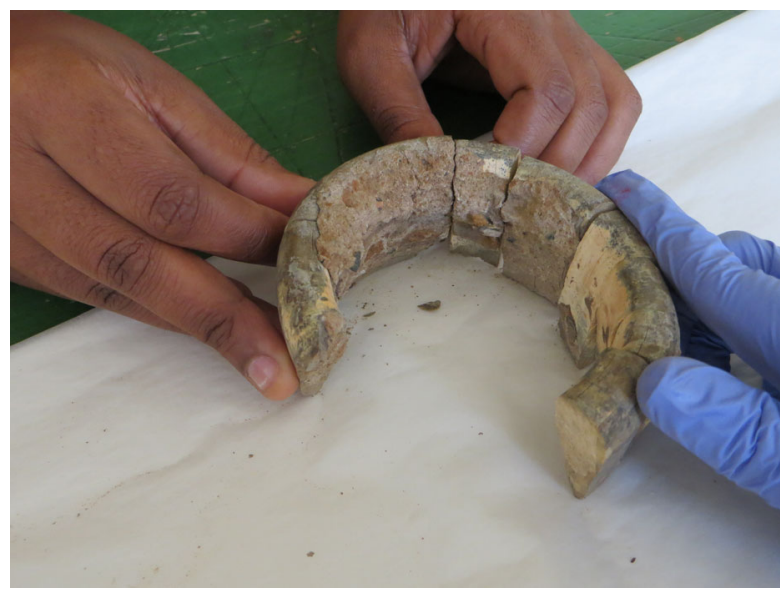




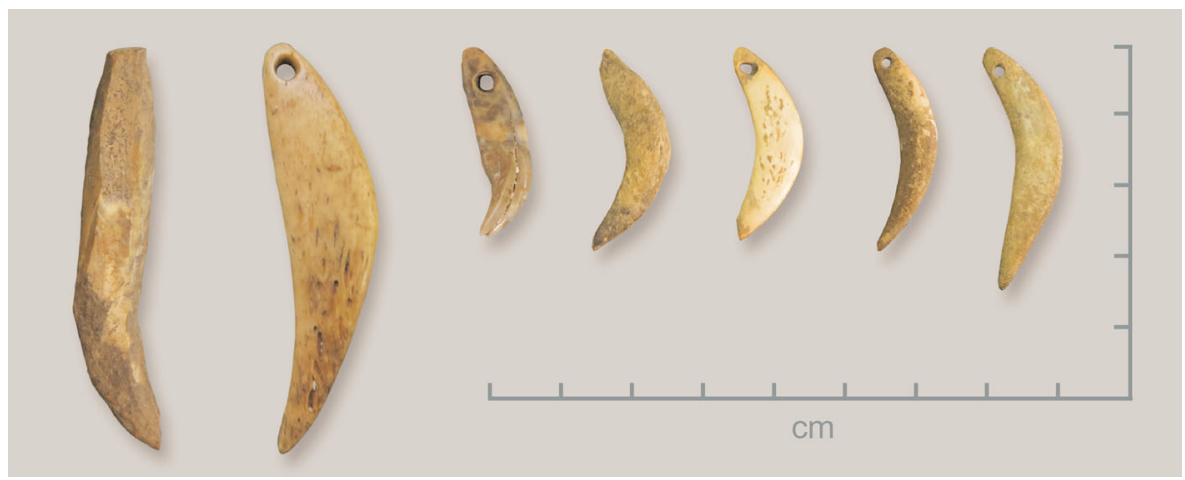

Fig. 4 From left to right, elephant ivory copy of canine tooth from KwaGandaganda, Square 25, Level 3 (UCT 14406, KZN no 13), bone copy of a canine tooth pierced for suspension from KwaGandaganda, Square 25, canine tooth pierced for suspension

demarcated an area where waste from these activities was deposited. The second phase of fieldwork extended the excavations into the Dung Area, interpreted as a cattle byre, and the Daga Area, an area of domestic activity. In addition, 12 auger samples were taken across the site to assess the presence of subsurface remains. The third phase of work expanded excavation of the Dung and Daga areas and also investigated additional middens to the east of earlier excavations. These yielded mainly domestic debris, although one locality revealed evidence from KwaGandaganda, Trench 6, and four bone copies of canine teeth, three with perforations, from Ndondondwane, Mound Area (photos-A. Coutu)

of charcoal and ore preparation. The occupation at Ndondondwane dates to the ninth century AD based on both radiocarbon dates and similarity in the ceramics recovered across the site; this is the name site of the Ndondondwane phase of the ceramic sequence for the region (Greenfield and van Schalkwyk 2003; Loubser 1993; Maggs 1984b). In this respect, it contrasts with many other Early Iron Age sites in the region at which occupation extended over more than one ceramic phase (see descriptions of KwaGandaganda and Wosi below).
Fig. 5 Site map of

Ndondondwane, re-drawn from

Maggs (1984b, p. 73) and

Loubser (1993, p. 111). Squares represent excavated areas, triangles represent auger sampling locations and stars indicate areas where ivory was found. Ivory samples taken for ZooMS and isotope analysis listed in Table 1 are from the excavation areas labelled on the map

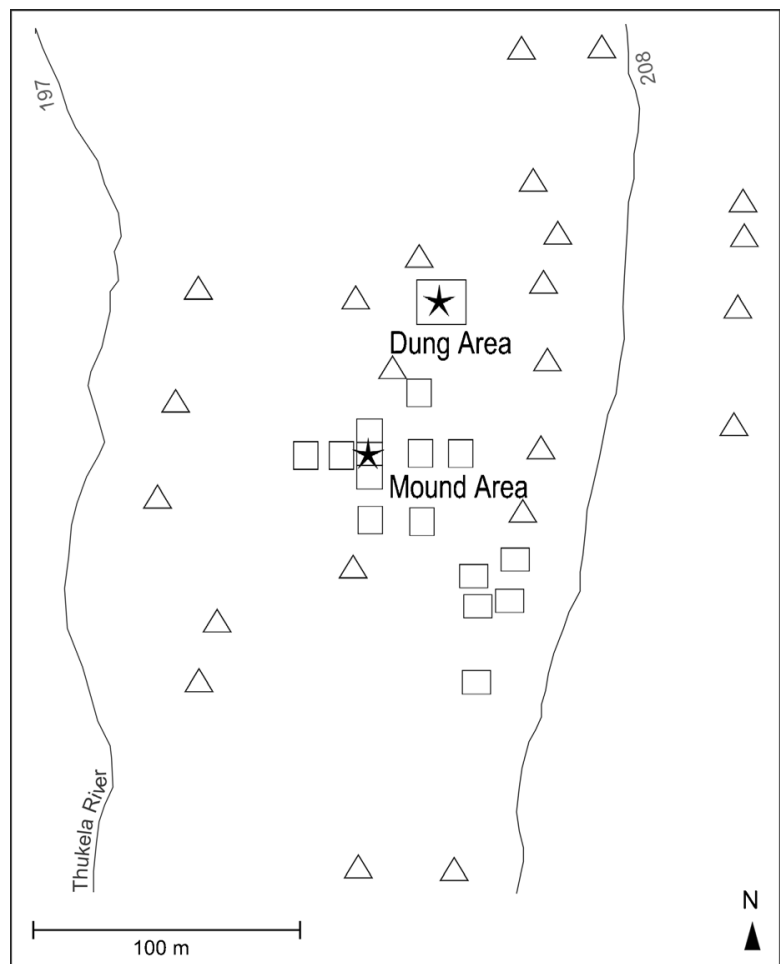


Food waste includes both domesticated and wild species. The bulk of the remains are domesticated animals, including cattle, sheep, goats, chickens and dogs. Elephant (represented almost entirely by ivory) and hippopotamus are notable among the wide variety of wild species identified, not all of which are game animals (Fread 2007; Voigt and Von den Driesch 1984).

Ivory fragments come overwhelmingly from the Mound Area, which was likely a specialised craft activity zone (Maggs 1984b). It is interesting to note the spatial co-distribution of the remains of iron working - a male activity throughout sub-Saharan Africaand ivory working, historically also a male activity amongst southern African Bantu speakers (Shaw 1974; Whitelaw 1994, 1994-1995). The initial excavation of the Mound Area, extending over $40 \mathrm{~m}^{2}$, produced 1,960 fragments of ivory waste weighing $1,150 \mathrm{~g}$ and also fragments of at least 22 armbands varying in thickness from 5 to $51 \mathrm{~mm}$ (Voigt and von den Driesch 1984). The amount of ivory present as well as the occurrence of both finished artefacts and working waste clearly indicate that the armbands were being manufactured on site. Near the Mound Area was what appeared to be a dump of hippopotamus bones, close to the river. These derived from at least four individuals, with 173 bones present, some still articulated and many showing butchering marks (Voigt and von den Driesch 1984). These authors suggested that this was a butchering site adjacent to the river, to avoid unnecessary transport of heavy carcasses. There was also a large unworked hippopotamus ivory fragment found in the Dung Area during the 1995 excavations. The abundance of hippopotamus remains raises the question of whether some of the worked ivory on the site might be hippopotamus, rather than elephant ivory.

Excavations at Ndondondwane also yielded a number of ostrich eggshell beads. Ostriches do not occur in bushy environments such as the Thukela Valley. Maggs (1984b) noted that none of the ostrich eggshell beads he recovered were broken in the course of manufacture, as often seen at sites in drier parts of South Africa. Beads made from the shell of the locally available land snail Metachatina, however, included several examples broken during manufacture. Maggs inferred that ostrich eggshell beads were not made on site, but imported from some distance away, probably from the grasslands to the west. A copper bead (Maggs 1984b) and three short pieces of copper wire (Loubser 1993) were probably also trade items. There is no evidence for local copper production at this time and copper objects were probably traded from copper-rich regions north of the Vaal River (Miller and Whitelaw 1994).

\section{KwaGandaganda}

KwaGandaganda was excavated from 1986 to 1989 by Whitelaw, as part of a cultural resource management project in the Mngeni Valley before the construction of the Inanda Dam (Whitelaw 1994). The site is now flooded by the dam. An area of almost $300 \times 400 \mathrm{~m}$ was investigated by scraping away strips of topsoil with a bulldozer to assess the presence of ceramics and other archaeological remains (Fig. 6). Subsequent excavation targeted the richest areas, different types of remains and different ceramic phases. Occupation at KwaGandaganda extended through the Msuluzi, Ndondondwane and Ntshekane ceramic phases, from the seventh to early eleventh century AD. The middle phase of occupation at $\mathrm{KwaGandaganda}$ is therefore contemporaneous with that at Ndondondwane.

The highest density of ivory at KwaGandaganda was found in Square 25. Here, excavations extending across $18 \mathrm{~m}^{2}$ yielded $3,659.7 \mathrm{~g}$ of ivory shavings and 10 fragments of ivory bangles (Whitelaw 1994) ranging in thickness from 18 to $27 \mathrm{~mm}$. Square 25 also yielded Msuluzi phase pottery, metal and ostrich eggshell beads, worked bone, fragments of ceramic sculpture and canine teeth pierced for suspension. This concentration of material therefore dates to the Msuluzi phase and the ivory predates that at the ninth century AD site of Ndondondwane. Clearly, ivory procurement and the manufacture of bangles/armlets were already well established in the seventh and eighth centuries $\mathrm{AD}$ in KwaZulu-Natal.

A second concentration of ivory was found in Square 22, a Ndondondwane phase midden located close to a cattle byre. Here, finds included domestic ceramics and ceramic sculpture, faunal material, ivory shavings and an entire elephant tusk measuring $80 \mathrm{~cm}$ in length. Other Ndondondwane phase ivory includes a thick elephant ivory bangle recovered from the red crust in Grid 4 (Fig. 3), ivory shavings from Byre 1 (Grid 4) and Byre 2 (Grid 3) and armlet fragments from Byres 1 and 4 (Test Square 5). Skeletal elements identified as elephant were found in all phases: 11 in the Msuluzi, 5 in the Ndondondwane and 3 in the Ntshekane phase (Beukes 2000). In contrast to the large quantity of hippopotamus remains at Ndondondwane, only five identifiable 
Fig. 6 Site map of

KwaGandaganda, re-drawn from

Whitelaw (1994, pp. 5-6).

Squares represent excavated areas, triangles represent survey points and archaeological features, and stars represent areas of site where ivory was found. Ivory samples taken for ZooMS and isotope analysis listed in Table 1 are from the excavation areas labelled on the map

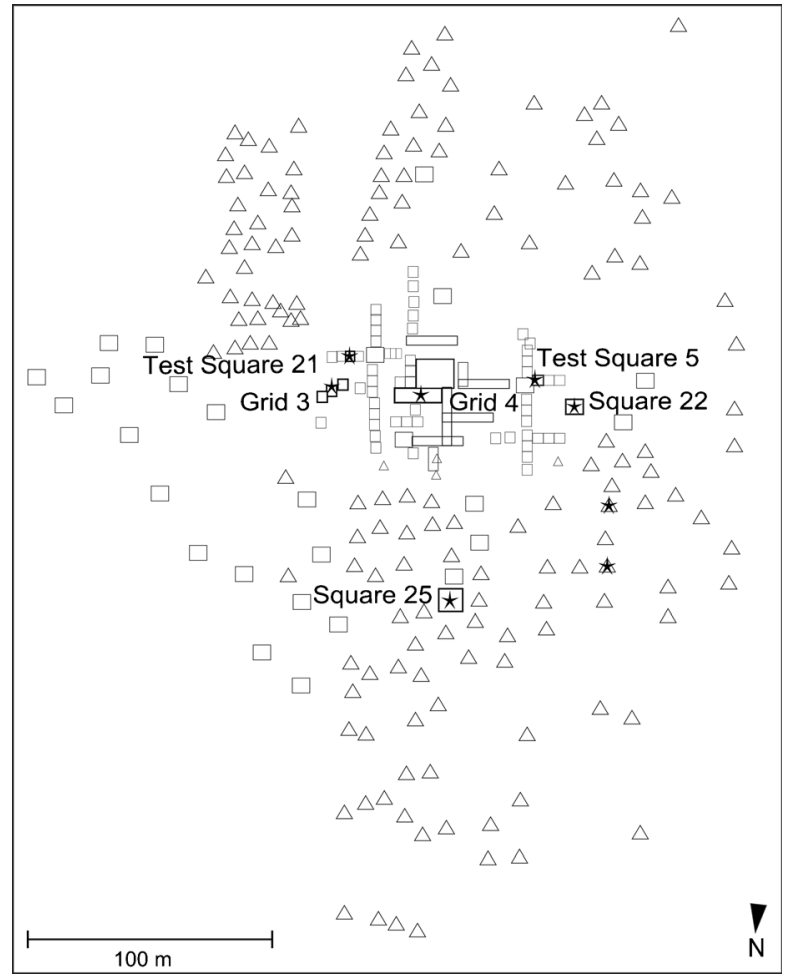

glazed ceramics thus far in southern Africa: a single sherd similar to ware recovered from ninth century $\mathrm{AD}$ sites in Iraq (Miller and Whitelaw 1994). One Zhizo series glass bead was found at the point of contact between Pits 2 and 4 in Grid 6. Based on ceramic style, the two pits date to the ninth and tenth centuries $\mathrm{AD}$ (see Whitelaw 1994, p. 17).

\section{Wosi}

The site of Wosi lies at the confluence of the Thukela and Wosi rivers and extends over 10 ha. Six middens were excavated with extensive work carried out on the largest midden (Grid II) (Fig. 7). Occupation at Wosi occurred primarily in the Msuluzi and Ndondondwane phases. Ceramic sculptures of animal and human figures, similar to those excavated at Ndondondwane, were found in Grid II. Shell disc beads $(n=1,742)$, made from the large land snail Metachatina kraussi, suggest a closed, wooded habitat, as this species requires shade (van Schalkwyk 1994). Faunal species such as blue duiker (Philantomba monticola) also signal a woodland-savanna or forest environment, further evidence for a relatively closed, bushy landscape around Wosi at the time of occupation (Voigt and Peters 1994). 
Fig. 7 Site map of Wosi, redrawn from van Schalkwyk (1994, p. 66). Squares represent excavated areas, triangles represent surveyed middens and stars represent areas of site where ivory was found. Ivory samples taken for ZooMS and isotope analysis listed in Table 1 are from the excavation areas labelled on the map

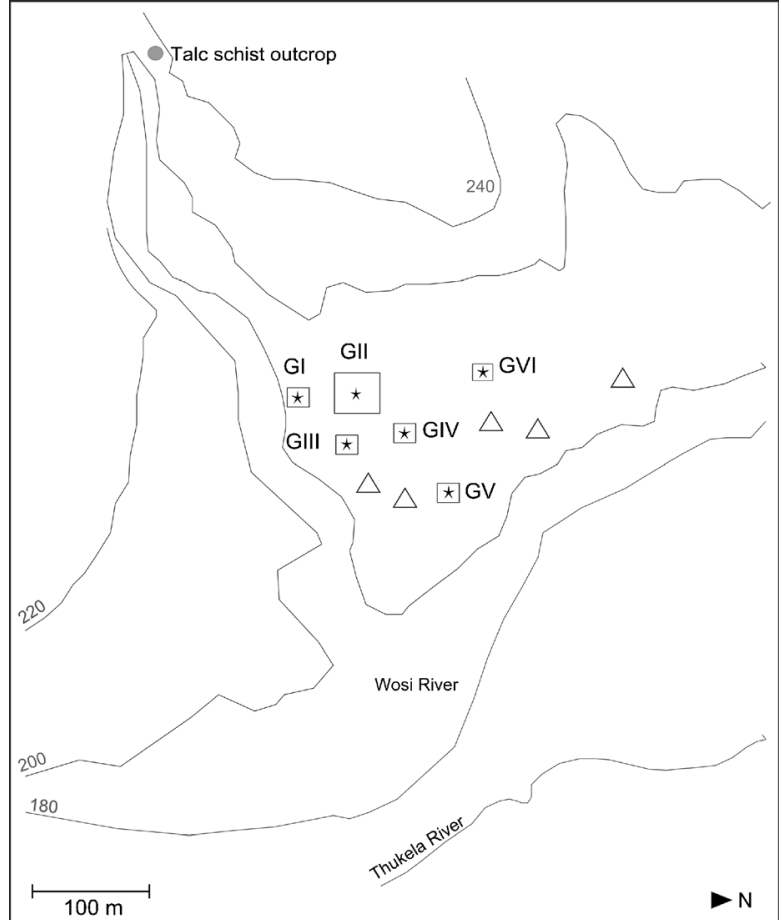

from marine shells provide evidence of coastal connections (Voigt and Peters 1994). The occurrence of stone artefacts, conforming to standardised Later Stone Age types, suggests interaction between hunter-gatherers and early farming communities. Trade in ivory may well have played a part in this interaction.

\section{Other Early Iron Age Sites}

Early Iron Age sites contemporary with KwaGandaganda, Ndondondwane and Wosi, but located further inland, have not yielded significant quantities of ivory. Msuluzi Confluence is the name site of the Msuluzi Phase and thus contemporary with Square 25 at KwaGandaganda and the lower levels at Wosi. This site lies on the Thukela River, upriver from Ndondondwane and Wosi (Fig. 1). It is a large site and since the excavations extended over only a limited area, there may be some as-yet-undiscovered ivory. Faunal preservation was poor, but the faunal sample recovered thus far lacks ivory (Maggs 1980). A single cowry shell and three ostrich eggshell beads provide evidence of trade or exchange with communities further afield. The sites of Magogo and Mhlopeni, in the Muden area slightly to the south-east (Fig. 1), also have not yielded significant amounts of ivory, although there is a single ivory bangle fragment in the sizeable faunal assemblage from Magogo 
(Voigt 1984). The ivory working fragments that are so prominent at KwaGandaganda, Ndondondwane and Wosi were not found. Twenty-seven ostrich eggshell beads were recovered from Magogo, as well as one marine shell (Monodonta australis), drilled for suspension, and one estuarine shell (Nassarius kraussianus). Later deposits at Ntshekane and site 2931AD17 yielded one Zhizo glass bead each (Maggs and Michael 1976, p. 726; KwaZuluNatal Museum records).

\section{Identifying Ivories}

Ivory is a specialised tooth that grows outwardly, protruding from the mouth of the animal, and is composed primarily of dentine. Although the term ivory is usually associated with the upper incisors of an elephant, technically many species grow ivory; in this paper, we consider elephant, hippopotamus and warthog as possible sources of southern African ivory. Hippopotamus ivory may derive from the upper or lower canines, which have a distinctive curved shape, or the incisors, which are straight. Warthog ivory originates from the upper or lower canines, which have deeply grooved surfaces and strong curvature. They are much larger than the small tusks of the bushpig (Potamochoerus larvatus). All of these ivories can be identified by a trained analyst by eye or by microscope, on the basis of the growth structure of the dentine. Elephant ivory has a distinctive growth pattern in that it grows outwards throughout the life of the elephant in a cone-in-cone structure. This structure produces an effect called the Schreger pattern, visible even to the naked eye when examining elephant ivory in crosssection (Locke 2008; Raubenheimer et al. 1990). It is, however, necessary to have relatively large pieces of ivory in order to see these patterns, and many of the ivory fragments found at Iron Age sites in southern Africa are small, especially waste from ivory working (Fig. 2). These require biomolecular methods for identification.

Large caches of hippopotamus ivory have been found at Iron Age trading sites such as Gao in West Africa (Insoll 1995). Since all three of the KwaZulu-Natal sites investigated here are riverine sites, and several butchered hippopotami were found at Ndondondwane, it was unclear whether hippopotamus ivory was also being used to make artefacts such as bangles. We therefore wanted to investigate whether ivory fragments at these three sites were consistently derived from elephant or might have come from diverse species.
Biomolecular Methods for Identifying Ivories

ZooMS is a method of taxonomic identification based upon peptide mass fingerprinting (the acronym ZooMS and method defined by van Doorn 2014); when applied to ivory and other skeletal hard tissues, it uses the structural protein collagen. Differences in the sequence of amino acids in the collagen of various species result in characteristic peptide profiles. In combination with a knowledge of the archaeozoology of the site, it is possible to use these to identify unknown fragments of bone, tooth or other materials (e.g., hair, Hollemeyer et al. 2012; or eggshell, Stewart et al. 2014). Very small amounts of collagen are extracted, converted to gelatin and the gelatin enzymatically fragmented into small peptides. The masses of these peptides are determined by time-of-flight mass spectrometry and compared with known reference sequences (Buckley et al. 2009, 2010; Buckley and Collins 2011; Kirby et al. 2013; von Holstein et al. 2014). Collagen is more robust than DNA, and ZooMS requires smaller samples than equivalent DNA sequencing analysis, so it was the preferred method here. Indeed, ZooMS analysis can be effectively nondestructive since a sample sufficient for analysis may be obtained by rubbing the surface of the object with a PVC eraser and analysing the peptide sequences in the protein remaining on the eraser "crumbs" (Fiddyment et al. 2015). ZooMS is an effective way to distinguish between hippopotamus and elephant because these two species have distinctive mass spectra (Fig. 8; Buckley et al. 2009). If one of the peptides characteristic of elephant or hippopotamus is preserved, it is often possible to distinguish between the two species even if the overall quality of the spectrum is poor due to bad protein preservation. ZooMS cannot distinguish between the two species of African elephant: forest (Loxodonta cyclotis) and savanna (Loxodonta africana). In Early Iron Age KwaZulu-Natal, only savanna elephants would have been present in the landscape.

\section{Isotopes as Tracers of Diet and Environment}

\section{Carbon Isotopes}

In tropical and subtropical Africa, where rain falls predominantly in the summer, most grasses utilise the $\mathrm{C}_{4}$ photosynthetic pathway, while shrubs, trees and other 
Fig. 8 Mass spectra from elephant (grey) and hippopotamus (black) reference samples, showing the difference in peptide mass to charge ratio versus peak intensity for each species

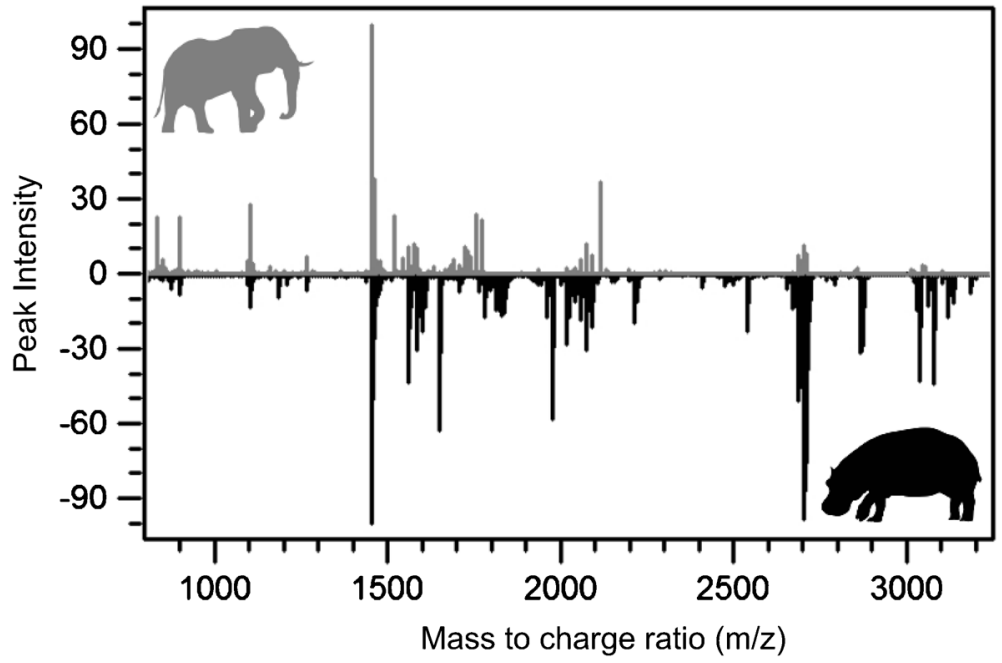

dicotyledonous plants utilise the $\mathrm{C}_{3}$ pathway. These two pathways result in very different ${ }^{13} \mathrm{C} /{ }^{12} \mathrm{C}$ ratios in plant tissue. Carbon isotope ratios are expressed as $\delta^{13} \mathrm{C}$ values, $\mathrm{w}$ h e $\mathrm{r}$ e

$\delta^{13} \mathrm{C}_{\text {sample }}=\left({ }^{13} \mathrm{C} /{ }^{12} \mathrm{C}_{\text {sample }}{ }^{13} \mathrm{C} /{ }^{12} \mathrm{C}_{\text {standard }}-1\right) \times 1000 \%$; the standard is Pee Dee Belemnite (PDB) which by definition has $\delta^{13} \mathrm{C}=0 \%$ o. Samples with negative $\delta^{13} \mathrm{C}$ values therefore contain less of the heavy ${ }^{13} \mathrm{C}$ isotope than the standard, while those with positive values contain more. The mean $\delta^{13} \mathrm{C}$ for modern $\mathrm{C}_{3}$ plants is $-27.1 \pm 1.6 \%$, with a range from -20 to $-37 \%$ (Kohn 2010). The mean for modern $\mathrm{C}_{4}$ grasses is $-12.5 \pm 1.1 \%$ with a range from -9 to $-17 \%$ o (Cerling et al. 1997). The greater range in $C_{3}$ plants is due to wide diversity of habitats and also to environmentally induced shifts in $\delta^{13} \mathrm{C}$ as a result of variations in moisture, light, temperature and similar factors. Before the Industrial Revolution and the combustion of large quantities of fossil fuels, $\delta^{13} \mathrm{C}$ of atmospheric carbon dioxide and of food chains as a whole were approximately $1.5 \%$ more positive than today (Francey et al. 1999). We have taken this into account in our interpretation of the analyses of archaeological ivory.

The carbon isotope composition of consumers reflects the foods consumed. Most tissues have more positive $\delta^{13} \mathrm{C}$ than the food due to further partitioning of carbon isotopes during digestion and tissue synthesis. Elephants are mixed feeders, relying on both $\mathrm{C}_{3}$ browse and $\mathrm{C}_{4}$ graze; hippopotami are primarily grazers; and warthogs are solely grazers. $\delta^{13} \mathrm{C}$ values of ivory can therefore be used to discriminate between species. African savanna elephant diets are seasonally variable, with animals tending to graze in the wet season, when fresh new grass is available, and browse in the dry season (Skinner and Chimimba 2005). This pattern has been documented in both East and South Africa in $\delta^{13} \mathrm{C}$ measurements of sequential subsamples of elephant hair (Cerling et al. 2009) and multiple small samples of ivory from cross-sections of tusks (Codron et al. 2012). Such isotopic heterogeneity has implications for the sampling strategy in this study (see below).

Comparison of the $\delta^{13} \mathrm{C}$ values of elephants and hippopotami in East Africa shows that elephants have more negative values, as expected given that a considerable proportion of their diet is $\mathrm{C}_{3}$ browse (Ambrose and DeNiro 1986; Tieszen and Imbamba 1980). The difference between the two species is, however, geographically and temporally variable, depending on the local environment and vegetation (Cerling et al. 2007, 2008). This will need to be determined for the Early Iron Age of KwaZulu-Natal, especially since river valleys were more densely vegetated at that time. Warthog in both East and South Africa show $\delta^{13} \mathrm{C}$ values typical of $\mathrm{C}_{4}$ grazers (Ambrose and DeNiro 1986; Botha and Stock 2005; Cerling et al. 2008; Codron et al. 2007; Tieszen and Imbamba 1980).

Isotope values for collagen extracted from ivory (dentine) are very similar to those for bone collagen, although it should be noted that dentine is laid down incrementally and does not remodel as bone does. The large number of $\delta^{13} \mathrm{C}$ values for bone collagen from modern southern African mammals suggest that animals that eat only browse $\left(\mathrm{C}_{3}\right.$ plants) have $\delta^{13} \mathrm{C}_{\text {collagen of about }}$ $-21 \%$, while those eating only $\mathrm{C}_{4}$ grasses have values 
of about $-7 \%$ (Codron et al. 2012; Lee-Thorp et al. 1989; Sponheimer et al. 2003a; Vogel 1978). Animals consuming a mixture of the two have intermediate $\delta^{13} \mathrm{C}$ values, depending on the proportions of graze and browse. Variations in moisture and temperature that affect the $\delta^{13} \mathrm{C}$ values of plants (especially $\mathrm{C}_{3}$ plants) can lead to small variations in consumer $\delta^{13} \mathrm{C}$.

\section{Nitrogen Isotopes}

Variation in stable nitrogen isotopes $\left({ }^{15} \mathrm{~N} /{ }^{14} \mathrm{~N}\right)$ is more complex and less well understood than variation in carbon isotopes. This is, in part, because of the complexity of the nitrogen cycle, with a large number of steps involved in nitrogen fixation and conversion of fixed nitrogen between different species. $\delta^{15} \mathrm{~N}$ values (calculated in the same way as $\delta^{13} \mathrm{C}$, the standard is atmospheric $\mathrm{N}_{2}$ or AIR) of soils, plants and animals tend to be higher in arid environments (Amundson et al. 2003; Aranibar et al. 2004; Murphy and Bowman 2006, 2009). They are typically also higher in animals that obtain most of their moisture requirements from their food, compared with those that drink water regularly (Ambrose and DeNiro 1986; Ambrose 1991; Sponheimer et al. 2003b). Since elephant, hippopotamus and warthog are all water-dependent (Skinner and Chimimba 2005), we do not expect inter-species differences in $\delta^{15} \mathrm{~N}$ to be as large as those in $\delta^{13} \mathrm{C}$. Wet/ dry season variation in $\delta^{15} \mathrm{~N}$ of growth increments of elephant hair and ivory is less pronounced than in $\delta^{13} \mathrm{C}$ (Cerling et al. 2009; Codron et al. 2012).

Previous studies of African fauna (including elephants) have documented a negative correlation between $\delta^{15} \mathrm{~N}$ in animal tissues and mean annual precipitation (Coutu 2011; Heaton et al. 1986; Ishibashi et al. 1999; van der Merwe et al. 1990). Elephants living in moist areas may have $\delta^{15} \mathrm{~N}$ as low as $2 \%$, while in arid areas (Ethiopia, Namibia and Somalia) values up to $17 \%$ have been recorded, although there is considerable variation according to local nitrogen cycling (Coutu 2011; van der Merwe et al. 1990).

\section{Strontium Isotopes}

Strontium isotope ratios $\left({ }^{87} \mathrm{Sr} /{ }^{86} \mathrm{Sr}\right)$ vary in different geological formations depending on the relative amounts of $\mathrm{Rb}$ (rubidium) and $\mathrm{Sr}$ that the rock contains, and the age of the formation. ${ }^{87} \mathrm{Rb}$ is radioactive and decays to ${ }^{87} \mathrm{Sr}$, hence older rocks or those with high $\mathrm{Rb} /$
Sr elemental abundance ratios evolve to high presentday ${ }^{87} \mathrm{Sr} /{ }^{86} \mathrm{Sr}$ values. In KwaZulu-Natal, the geology in the environs of Wosi and Ndondondwane consists of very ancient, highly metamorphosed rocks, mainly gneisses of the Dondwana Gneiss Unit, part of the Mandleni tectonostratigraphic package of the Tugela terrane which forms the northernmost part of the Natal Belt (Johnston et al. 2002). There is, however, considerable complexity, with many intrusions. KwaGandaganda lies in the deeply incised Mngeni Valley (Valley of a Thousand Hills) which cuts through younger Karoo sedimentary rocks into older granite. The surrounding highlands consist of Natal Group sandstones/quartzites and Karoo sedimentaries (Fig. 9). Soils in river valleys may be mixed if the rivers carry down sediments from geological formations upstream. In addition, biologically available strontium can have isotope ratios that differ from whole-rock values if the various components of the rock are differentially soluble and have varied ${ }^{87} \mathrm{Sr} /{ }^{86} \mathrm{Sr}$ (Hodell et al. 2004; Sillen et al. 1998).

For these reasons, Arnold et al. (2013) measured nine modern Achatina shells from the lower Thukela Valley to assess bioavailable ${ }^{87} \mathrm{Sr} /{ }^{86} \mathrm{Sr}$, obtaining values between 0.7081 and 0.7159 . As these authors note, this is a large range. This is unsurprising given that the local geology can be extremely variable. It should be noted that individual specimens of Achatina have limited mobility, so ${ }^{87} \mathrm{Sr} /{ }^{86} \mathrm{Sr}$ of single shells represent values integrated over small areas. More mobile species such as cattle and elephants will average ${ }^{87} \mathrm{Sr} /{ }^{86} \mathrm{Sr}$ over larger scales. Analyses of archaeological cattle teeth from the sites of Ndondondwane, Wosi and Mamba (very close to Wosi) yielded a range of 0.7094 to 0.7216 . Extreme values were thought to indicate animals brought in from outside the Thukela Valley (Arnold et al. 2013).

${ }^{87} \mathrm{Sr} /{ }^{86} \mathrm{Sr}$ measurements on modern small mammals from different geological formations in KwaZulu-Natal analysed by the authors are as follows: 0.71706 to 0.71931 for three samples from the Natal Group, 0.71448 to 0.71686 for three samples from Karoo dolerite, 0.71229 to 0.71558 for 10 samples from Ecca/ Beaufort and 0.71022 to 0.71304 for three samples from the Berea group (see Supplementary Material Online for data and Fig. 9 for a schematic diagram of the geology of KwaZulu-Natal).

Thus, while the geology in the environs of KwaGandaganda, Ndondondwane and Wosi is complicated, ${ }^{87} \mathrm{Sr} /{ }^{86} \mathrm{Sr}$ measurements of archaeological ivory 


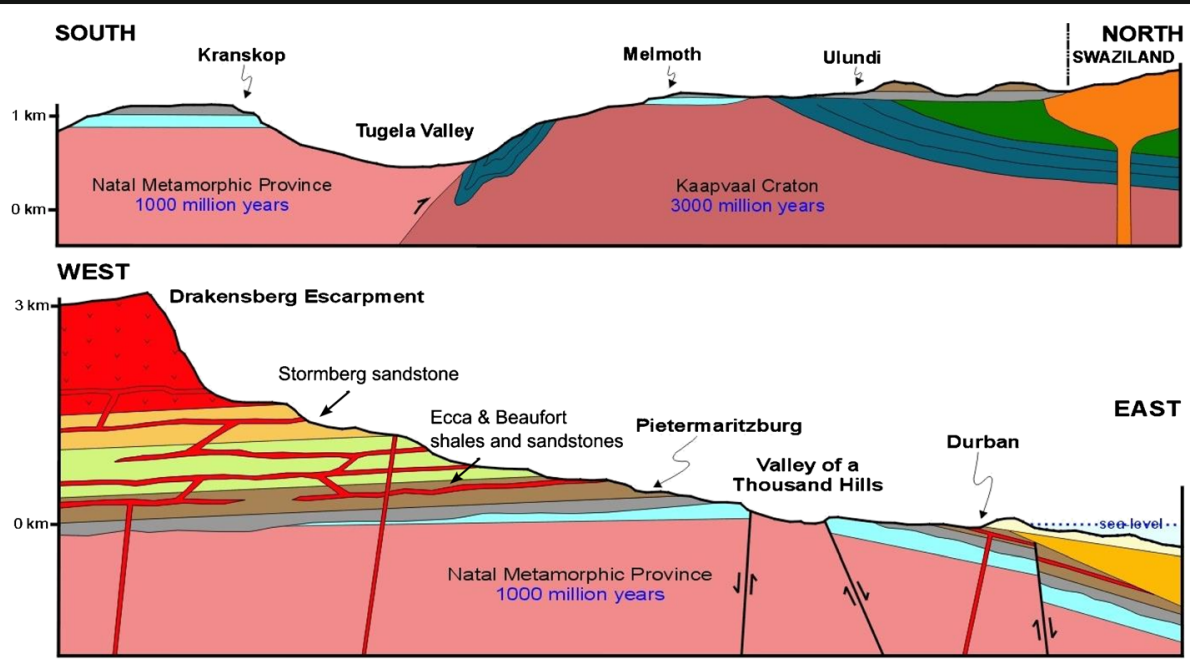

Fig. 9 Geological map of the KwaZulu-Natal region (Whitmore et al. 1999)

may be able to cast some light on the geological substrates on which the elephants lived, complementing information obtained from carbon and nitrogen isotopes.

\section{Laboratory Methods}

\section{Carbon and Nitrogen Isotope Analysis}

Elephant, hippopotamus and warthog ivory grows continuously and incrementally throughout the lifetime of the animal. In order to obtain meaningful isotopic measurements for each ivory fragment, it is important to sample across multiple growth layers. A guiding principle in our sampling strategy was to take sufficiently large, clean pieces, oriented in such a way that ivory from more than one season was incorporated into the material analysed. As far as possible, an effort was also made to select samples from different spatial and stratigraphic units within each archaeological site, in order to minimise the chances of repeat sampling pieces from an individual tusk.

For collagen extraction, fragments were removed or the object was drilled using a clean diamond-tip drill bit on a Dremel hand drill and the sample collected as powder. Collagen extraction followed the method of O'Connell and Hedges (1999) with some modifications. Briefly, cleaned chips or ivory powders were demineralised in $0.3 \mathrm{M} \mathrm{HCl}$ at room temperature for a period of up to 1-2 weeks, then rinsed with distilled water. They were then treated with $0.1 \mathrm{M} \mathrm{NaOH}$ to remove humic acids derived from the burial environment, then rinsed with distilled water. The samples were then put into $\mathrm{pH} 3,0.01 \mathrm{M} \mathrm{HCl}$ and heated to $70{ }^{\circ} \mathrm{C}$ for $48 \mathrm{~h}$ to denature the collagen ("gelatinization"). They were then filtered through 60-90 $\mu \mathrm{m}$ Ezee® filters to remove large debris and subsequently lyophilised for analysis.

Approximately $0.5 \mathrm{mg}$ of each sample was weighed into a tin capsule for combustion into $\mathrm{N}_{2}$ and $\mathrm{CO}_{2}$ gases on a Thermo Flash Elemental Analyser 2000. These were then introduced to a Delta V Plus mass spectrometer for measurement of ${ }^{13} \mathrm{C} /{ }^{12} \mathrm{C}$ and ${ }^{15} \mathrm{~N} /{ }^{14} \mathrm{~N}$ ratios as well as elemental compositions $(\% \mathrm{C}, \% \mathrm{~N})$. The results are expressed in the delta $(\delta)$ notation in parts per thousand $(\% \circ)$, relative to the international standards Vienna Pee Dee Belemnite (VPDB) for carbon and Ambient Inhalable Reservoir (AIR) for nitrogen. All samples were run in duplicate and the results averaged to give the values listed in Table 1 . The reproducibility of repeated measurements of homogeneous standard materials was $0.2 \%$ or better for both carbon and nitrogen.

\section{Strontium Isotope Analysis}

Strontium isotope analysis was performed in the Department of Geological Sciences at the University of Cape Town. Four samples were subjected to a leaching experiment in order to assess whether the ivory might have absorbed $\mathrm{Sr}$ from the burial environment, leading to erroneous assessment of ${ }^{87} \mathrm{Sr} /{ }^{86} \mathrm{Sr}$. Post-depositional contamination (or diagenesis) may occur via Sr adsorption or incorporation of contaminating ions into 
Table 1 ZooMS and isotope data for all samples analysed in this study

\begin{tabular}{|c|c|c|c|c|c|c|c|c|c|}
\hline $\begin{array}{l}\text { UCT } \\
\text { number }\end{array}$ & $\begin{array}{l}\text { KZN } \\
\text { number }\end{array}$ & $\begin{array}{l}\text { ZooMS } \\
\text { ID }\end{array}$ & $\begin{array}{l}\delta^{15} \mathrm{~N} \\
(\% o)\end{array}$ & $\begin{array}{l}\% \mathrm{~N} \text { (by } \\
\text { weight) }\end{array}$ & $\begin{array}{l}\delta^{13} \mathrm{C} \\
(\% o)\end{array}$ & $\begin{array}{l}\% \mathrm{C} \text { (by } \\
\text { weight) }\end{array}$ & $\begin{array}{l}\mathrm{C} / \mathrm{N} \\
\text { (atomic) }\end{array}$ & ${ }^{87} \mathrm{Sr} /{ }^{86} \mathrm{Sr}$ & $\begin{array}{l}\text { Location within } \\
\text { site }\end{array}$ \\
\hline \multicolumn{10}{|c|}{ KwaGandaganda } \\
\hline 17450 & 60 & & 9.9 & 14.1 & -22.4 & 40.7 & 3.4 & & Grid 3 \\
\hline 17458 & 68 & & 7.0 & 15.0 & -19.4 & 41.9 & 3.3 & & Grid 3 \\
\hline 14415 & 22 & & 7.9 & 11.8 & -21.2 & 31.8 & 3.2 & & Grid 4 \\
\hline 14414 & 21 & & & & & & & \multirow[t]{3}{*}{0.71612} & Grid 6 \\
\hline 14401 & 8 & & 9.8 & 10.9 & -20.2 & 33.7 & 3.6 & & Test Square 5 \\
\hline 14402 & 9 & & 8.6 & 11.9 & -21.4 & 35.7 & 3.5 & & Test Square 21 \\
\hline 14409 & 16 & & & & & & & \multirow[t]{5}{*}{0.71712} & Test Square 22 \\
\hline 14397 & 4 & & 11.6 & 11.8 & -22.5 & 35.5 & 3.5 & & Square 22 \\
\hline 17451 & 61 & & 8.5 & 14.5 & -19.8 & 40.6 & 3.3 & & Square 22 \\
\hline 14405 & 12 & & 11.4 & 12.7 & -17.0 & 38.1 & 3.5 & & Square 25 \\
\hline 14407 & 14 & & 9.5 & 14.8 & -19.4 & 41.4 & 3.3 & & Square 25 \\
\hline 14411 & 18 & Elephant & 8.3 & 15.0 & -20.6 & 41.6 & 3.2 & \multirow[t]{7}{*}{0.71548} & Square 25 \\
\hline 14413 & 20 & & 7.8 & 13.5 & -20.2 & 37.8 & 3.3 & & Square 25 \\
\hline 17452 & 62 & Elephant & 9.6 & 14.6 & -18.7 & 41.2 & 3.3 & & Square 25 \\
\hline 17464 & 74 & & 9.3 & 14.9 & -19.6 & 42.0 & 3.3 & & Square 25 \\
\hline 17465 & 75 & & 7.4 & 14.9 & -20.0 & 41.4 & 3.2 & & Square 25 \\
\hline 17488 & 98 & & 7.6 & 14.5 & -20.2 & 40.9 & 3.3 & & Square 25 \\
\hline 17456 & 66 & & 9.0 & 14.9 & -19.5 & 42.0 & 3.3 & & Square $25 \mathrm{a}$ \\
\hline 17457 & 67 & Elephant & 9.4 & 14.7 & -18.8 & 41.1 & 3.3 & & Square $25 \mathrm{a}$ \\
\hline 14403 & 10 & & 10.0 & 11.3 & -16.2 & 30.3 & 3.1 & & Square $25 b$ \\
\hline 14404 & 11 & & 7.4 & 12.1 & -21.0 & 33.2 & 3.2 & \multirow{7}{*}{0.71626} & Square $25 \mathrm{~b}$ \\
\hline 14410 & 17 & & 8.1 & 13.6 & -21.0 & 37.7 & 3.2 & & Square $25 \mathrm{~b}$ \\
\hline 17453 & 63 & Elephant & 13.0 & 16.2 & -17.3 & 45.4 & 3.3 & & Square $25 b$ \\
\hline 17459 & 69 & & 10.2 & 14.9 & -19.9 & 42.5 & 3.3 & & Square $25 \mathrm{~b}$ \\
\hline 17460 & 70 & & 8.6 & 15.5 & -20.0 & 43.0 & 3.2 & & Square $25 \mathrm{~b}$ \\
\hline 17461 & 71 & Elephant & 10.3 & 15.3 & -16.9 & 42.4 & 3.2 & & Square $25 \mathrm{c}$ \\
\hline 14406 & 13 & Elephant & 14.3 & 13.5 & -17.3 & 37.9 & 3.3 & & Square $25 \mathrm{~d}$ \\
\hline 14412 & 19 & & 7.1 & 14.1 & -20.9 & 42.6 & 3.5 & \multirow[t]{4}{*}{0.71498} & Square $25 \mathrm{~d}$ \\
\hline 17454 & 64 & & 11.8 & 14.5 & -19.1 & 42.5 & 3.4 & & Square $25 \mathrm{~d}$ \\
\hline 17455 & 65 & Elephant & 11.0 & 14.6 & -17.1 & 41.6 & 3.3 & & Square $25 \mathrm{~d}$ \\
\hline 17491 & 101 & Elephant & 8.6 & 14.8 & -18.5 & 41.7 & 3.3 & & Square $25 \mathrm{~d}$ \\
\hline 17462 & 72 & & 7.8 & 14.7 & -20.0 & 40.8 & 3.2 & \multirow[t]{6}{*}{$0.71611^{*}$} & Square $25 \mathrm{e}$ \\
\hline 17463 & 73 & & 10.5 & 15.0 & -20.2 & 41.9 & 3.3 & & Square $25 \mathrm{e}$ \\
\hline 17466 & 76 & & 8.4 & 14.9 & -19.6 & 41.7 & 3.3 & & Square $25 \mathrm{e}$ \\
\hline 17467 & 77 & & 7.6 & 14.8 & -20.5 & 43.1 & 3.4 & & Square $25 \mathrm{e}$ \\
\hline 17468 & 78 & & 7.2 & 15.0 & -20.1 & 42.4 & 3.3 & & Square $25 \mathrm{e}$ \\
\hline 17469 & 79 & & 8.5 & 14.8 & -19.8 & 41.2 & 3.3 & & Square $25 \mathrm{e}$ \\
\hline 17470 & 80 & & 6.9 & 14.6 & -20.1 & 41.2 & 3.3 & \multirow[t]{4}{*}{$0.71532 *$} & Square $25 \mathrm{e}$ \\
\hline 17471 & 81 & & 8.1 & 14.3 & -22.2 & 40.0 & 3.3 & & Square $25 \mathrm{e}$ \\
\hline 17489 & 99 & & 7.9 & 15.1 & -20.0 & 41.9 & 3.2 & & Square $25 \mathrm{e}$ \\
\hline 17490 & 100 & & 8.1 & 15.1 & -20.3 & 42.0 & 3.3 & & Square $25 \mathrm{e}$ \\
\hline \multicolumn{10}{|c|}{ Ndondondwane } \\
\hline 17482 & 92 & & 9.4 & 15.5 & -22.6 & 43.9 & 3.3 & & $\mathrm{C} 10$ \\
\hline 14428 & 35 & & 7.4 & 15.0 & -20.4 & 42.2 & 3.3 & & E8 \\
\hline
\end{tabular}


Table 1 (continued)

\begin{tabular}{|c|c|c|c|c|c|c|c|c|c|}
\hline $\begin{array}{l}\text { UCT } \\
\text { number }\end{array}$ & $\begin{array}{l}\text { KZN } \\
\text { number }\end{array}$ & $\begin{array}{l}\text { ZooMS } \\
\text { ID }\end{array}$ & $\begin{array}{l}\delta^{15} \mathrm{~N} \\
(\% o)\end{array}$ & $\begin{array}{l}\% \mathrm{~N} \text { (by } \\
\text { weight) }\end{array}$ & $\begin{array}{l}\delta^{13} \mathrm{C} \\
(\% o)\end{array}$ & $\begin{array}{l}\% \mathrm{C} \text { (by } \\
\text { weight) }\end{array}$ & $\begin{array}{l}\mathrm{C} / \mathrm{N} \\
\text { (atomic) }\end{array}$ & ${ }^{87} \mathrm{Sr} /{ }^{86} \mathrm{Sr}$ & $\begin{array}{l}\text { Location within } \\
\text { site }\end{array}$ \\
\hline 14429 & 36 & & 7.6 & 13.1 & -21.0 & 39.2 & 3.5 & & E8 \\
\hline 17474 & 84 & & 7.7 & 14.8 & -20.4 & 41.5 & 3.3 & & E10 \\
\hline 14423 & 30 & & 7.6 & 14.7 & -21.2 & 40.8 & 3.2 & $\begin{array}{r}0.71255^{*} \\
0.71289\end{array}$ & G9 \\
\hline 14424 & 31 & Elephant & 10.1 & 14.8 & -19.3 & 42.8 & 3.4 & & G9 \\
\hline 14427 & 34 & Elephant & 10.2 & 14.5 & -21.0 & 40.6 & 3.3 & & G9 \\
\hline 17479 & 89 & & 7.4 & 15.6 & -20.4 & 43.7 & 3.3 & & G9 \\
\hline 17480 & 90 & & 6.1 & 14.5 & -20.8 & 40.5 & 3.2 & & G9 \\
\hline 17481 & 91 & & 8.3 & 14.5 & -20.6 & 40.9 & 3.3 & & G9 \\
\hline 14417 & 24 & & 12.2 & 12.8 & -20.5 & 35.3 & 3.2 & 0.71321 & G10 \\
\hline 14419 & 26 & & 7.6 & 14.2 & -20.6 & 41.0 & 3.4 & 0.71366 & G10 \\
\hline 17475 & 85 & & 11.1 & 14.7 & -20.7 & 41.4 & 3.3 & & G10 \\
\hline 17476 & 86 & & 8.2 & 15.0 & -20.8 & 41.8 & 3.2 & & G10 \\
\hline 17478 & 88 & Elephant & 7.6 & 14.9 & -18.6 & 42.1 & 3.3 & & G11 \\
\hline 14426 & 33 & Elephant & 9.9 & 12.7 & -20.7 & 35.4 & 3.3 & & G12 \\
\hline 14433 & 40 & & & & & & & 0.71242 & G12 \\
\hline 14446 & 52 & Elephant & 12.0 & 13.7 & -19.8 & 38.7 & 3.3 & & H9? \\
\hline 14448 & 54 & Elephant & 10.9 & 14.4 & -20.5 & 40.6 & 3.3 & & $\mathrm{H} 9$ ? \\
\hline 14420 & 27 & Elephant & 7.1 & 11.3 & -20.3 & 31.6 & 3.3 & 0.71398 & H10 \\
\hline 14421 & 28 & & 10.7 & 14.9 & -21.0 & 41.9 & 3.3 & 0.71329 & $\mathrm{H} 10$ \\
\hline 14422 & 29 & & & & & & & 0.71363 & H10 \\
\hline 17487 & 97 & & 8.8 & 14.4 & -21.7 & 40.4 & 3.3 & & H10 \\
\hline 14447 & 53 & Elephant & 12.0 & 14.5 & -19.3 & 42.2 & 3.4 & & H11 \\
\hline 14449 & 55 & Elephant & 7.9 & 14.3 & -20.4 & 41.5 & 3.4 & & H11 \\
\hline 14430 & 37 & & 7.7 & 14.8 & -19.3 & 41.9 & 3.3 & & $\mathrm{I} 10$ \\
\hline 17472 & 82 & & 11.3 & 15.1 & -21.9 & 42.8 & 3.3 & $0.71429 *$ & $\mathrm{I} 10$ \\
\hline 17484 & 94 & & 7.1 & 15.4 & -20.6 & 42.6 & 3.2 & & $\mathrm{I} 10$ \\
\hline 17485 & 95 & & 7.2 & 14.6 & -20.9 & 41.0 & 3.3 & & $\mathrm{I} 10$ \\
\hline 14431 & 38 & Elephant & 7.3 & 14.6 & -19.8 & 42.0 & 3.4 & $0.71268 *$ & K10 \\
\hline \multicolumn{10}{|c|}{ Ndondondwane Hippopotamus } \\
\hline 14450 & 56 & & 9.1 & 14.6 & -9.4 & 40.7 & 3.3 & & Dung Area \\
\hline 14434 & 41 & & 8.2 & 12.5 & -9.7 & 34.9 & 3.3 & 0.71497 & G10 \\
\hline 14436 & 43 & & 8.0 & 13.6 & -12.5 & 41.5 & 3.6 & & G10 \\
\hline \multicolumn{10}{|l|}{ Wosi } \\
\hline 17499 & 109 & & 10.5 & 14.4 & -19.4 & 41.6 & 3.4 & & Grid 1 \\
\hline 17494 & 104 & Elephant & 10.2 & 14.7 & -18.2 & 41.6 & 3.3 & & Grid 2 \\
\hline 17495 & 105 & Elephant & 12.7 & 14.8 & -15.2 & 41.1 & 3.2 & & Grid 2 \\
\hline 17497 & 107 & Elephant & 11.9 & 15.0 & -16.8 & 41.3 & 3.2 & & Grid 2 \\
\hline 17501 & 111 & & 8.9 & 14.8 & -20.0 & 41.5 & 3.3 & & Grid 2 \\
\hline 17504 & 114 & Elephant & 13.1 & 11.2 & -17.5 & 31.1 & 3.3 & & Grid 2 \\
\hline 17506 & 116 & Elephant & 11.7 & 14.8 & -18.3 & 41.2 & 3.2 & & Grid 2 \\
\hline 17509 & 119 & & 11.8 & 14.5 & -17.3 & 40.2 & 3.2 & $0.71289^{*}$ & Grid 2 \\
\hline 17510 & 120 & & 8.0 & 14.4 & -19.6 & 40.6 & 3.3 & & Grid 2 \\
\hline 17496-A & $106-\mathrm{A}$ & Elephant & 12.9 & 13.8 & -17.0 & 39.0 & 3.3 & & Grid 2 \\
\hline 17508 & 118 & Elephant & 12.3 & 14.9 & -17.0 & 41.8 & 3.3 & & Grid 3 \\
\hline 17500 & 110 & & 7.9 & 16.0 & -20.6 & 45.0 & 3.3 & & Grid 4 \\
\hline
\end{tabular}


Table 1 (continued)

\begin{tabular}{|c|c|c|c|c|c|c|c|c|}
\hline $\begin{array}{l}\text { UCT } \\
\text { number }\end{array}$ & $\begin{array}{l}\text { KZN } \\
\text { number }\end{array}$ & $\begin{array}{l}\text { ZooMS } \\
\text { ID }\end{array}$ & $\begin{array}{l}\delta^{15} \mathrm{~N} \\
(\% o)\end{array}$ & $\begin{array}{l}\% \mathrm{~N} \text { (by } \\
\text { weight) }\end{array}$ & $\begin{array}{l}\delta^{13} \mathrm{C} \\
(\% o)\end{array}$ & $\begin{array}{l}\% \mathrm{C} \text { (by } \\
\text { weight) }\end{array}$ & $\begin{array}{l}\mathrm{C} / \mathrm{N} \\
\text { (atomic) }\end{array}$ & $\begin{array}{l}\text { Location within } \\
\text { site }\end{array}$ \\
\hline 17502 & 112 & \multirow[t]{3}{*}{ Elephant } & 12.5 & 12.9 & -17.6 & 36.7 & 3.3 & Grid 4 \\
\hline 17503 & 113 & & 8.9 & 14.7 & -19.2 & 41.9 & 3.3 & Grid 4 \\
\hline 17505 & 115 & & 8.2 & 14.2 & -21.2 & 42.5 & 3.5 & Grid 6 \\
\hline \multicolumn{9}{|c|}{ Wosi hippopotamus } \\
\hline 17496 & 106 & & 6.5 & 14.4 & -10.5 & 43.6 & 3.5 & Grid 5 \\
\hline \multicolumn{9}{|c|}{ KwaZulu-Natal Museum historic elephants } \\
\hline 17492 & 102 & & 10.0 & 15.9 & -20.3 & 45.7 & 3.3 & Shot 1916 \\
\hline 17492-A & $102-\mathrm{A}$ & & 10.2 & 14.9 & -20.8 & 41.7 & 3.3 & Pre-1880 \\
\hline
\end{tabular}

$\overline{{ }^{87} \mathrm{Sr}}{ }^{86} \mathrm{Sr}$ values with asterisks indicate samples analysed by laser ablation MC-ICP-MS. Others were analysed by solution. For more detailed provenance information for each sample, please refer to Online Resource 3

recrystallised mineral. Either way, diagenetic material is more soluble than biogenic mineral, so that leaching in dilute acid preferentially removes the diagenetic component. Approximately $50 \mathrm{mg}$ of each powdered sample was washed 30 times in a $100 \mathrm{mM}$ acetic acid/sodium acetate buffer adjusted to $\mathrm{pH} 4.5$ following the method outlined in Sealy et al. (1991). If there is significant diagenetic contamination by $\mathrm{Sr}$ with an isotopic composition different from that of biogenic $\mathrm{Sr}$, then ${ }^{87} \mathrm{Sr} /{ }^{86} \mathrm{Sr}$ of the early washes should differ from the later washes. Every five washes were pooled for analysis of ${ }^{87} \mathrm{Sr} /{ }^{86} \mathrm{Sr}$. ${ }^{87} \mathrm{Sr} /{ }^{86} \mathrm{Sr}$ was also measured in the undissolved residue, using the solution method described below.

"Solution" analyses were carried out as follows. Up to $25 \mathrm{mg}$ of each ivory sample was dissolved in $2 \mathrm{ml}$ $65 \% 2 \mathrm{~B} \mathrm{HNO}_{3}$ in a closed Teflon beaker and placed on a hotplate at $140{ }^{\circ} \mathrm{C}$ for an hour. It was then dried down and re-dissolved in $1.5 \mathrm{ml} 2 \mathrm{M} \mathrm{HNO}_{3}$ for strontium separation chemistry, following the method of Pin et al. (1994). The separated strontium fraction for each sample was dried down, dissolved in $2 \mathrm{ml} 0.2 \% \mathrm{HNO}_{3}$ and diluted to $200 \mathrm{ppb} \mathrm{Sr}$ concentrations for isotope analysis using a $\mathrm{Nu}$ Instruments NuPlasma high resolution multi-collector inductively coupled plasma mass spectrometer (HR MC-ICP-MS). Analyses were referenced to bracketing analyses of NIST SRM987, using ${ }^{87} \mathrm{Sr} /{ }^{86} \mathrm{Sr}$ reference value of 0.710255 . All strontium isotope data are corrected for isobaric rubidium interference at $87 \mathrm{amu}$ using the measured signal for ${ }^{85} \mathrm{Rb}$ and the natural ${ }^{85} \mathrm{Rb} /{ }^{87} \mathrm{Rb}$ ratio. Instrumental mass fractionation was corrected using the measured ${ }^{86} \mathrm{Sr} /{ }^{88} \mathrm{Sr}$ ratio and the exponential law, and a true ${ }^{86} \mathrm{Sr} /{ }^{88} \mathrm{Sr}$ value of 0.1194 . Analytical error associated with measurements by solution is $\pm 0.00002(2 \sigma)$.
Laser ablation MC-ICP-MS Sr isotope analysis followed the procedure originally presented in Copeland et al. (2008) and recently evaluated further by le Roux et al. (2014). The same analytical instrumentation described in those publications, a NuPlasma MC-ICP-MS coupled to a NewWave UP-213 laser ablation unit, was used in this study. The error associated with ${ }^{87} \mathrm{Sr} /{ }^{86} \mathrm{Sr}$ measurements by laser ablation on this system is $\pm 0.0003(2 \sigma)$.

\section{ZooMS Analysis}

Selected samples were also analysed in the BioArCh laboratories for ZooMS at the University of York, UK. Where sufficient sample material was available, approximately $0.5 \mathrm{mg}$ of collagen extracted for stable isotope analysis as described above was used for ZooMS by heating in $50 \mathrm{mM}$ ammonium bicarbonate buffer at $65{ }^{\circ} \mathrm{C}$ for $1 \mathrm{~h}$ to solubilise a small fraction of the collagen. This soluble fraction was trypsinated overnight at $37{ }^{\circ} \mathrm{C}$ to break the protein into peptide fragments, which were then concentrated and eluted using C18 Zip Tips. Mass spectra (as shown in Fig. 8) were measured using a calibrated Ultraflex III (Bruker Daltonics) MALDI-TOF MS instrument in reflector mode and compared with reference spectra (Buckley et al. 2009).

\section{Results}

Collagen Quality Indicators

Collagen extracts in this study had $\mathrm{C} / \mathrm{N}$ ratios ranging from 3.1 to 3.6 (Table 1). Values between 2.9 and 3.6 are 
generally considered characteristic of collagen that is sufficiently well preserved that measurement of the stable isotope ratios will yield reliable results (Ambrose 1990; DeNiro 1985; Van Klinken 1999). \%C (by weight) varied from 30.2 to 45.4 and $\% \mathrm{~N}$ from 10.9 to 16.2 , also within the ranges seen in well-preserved collagen.

\section{ZooMS}

All of the 26 collagen samples analysed using ZooMS could be successfully identified to species, and all proved to be elephant ivory. Six of the samples were selected for ZooMS because "hippo?" was written on their museum labels, probably due to the presence of ridged surfaces resembling hippopotamus teeth. Another specimen, from Square 25 at KwaGandaganda (UCT 14406, KZN no 13), is an ivory copy of a perforated canine tooth like that found in the same context (Fig. 4) (Whitelaw 1994). The ZooMS results showed that this piece is also elephant ivory (spectra in Online Resource 1). All of the worked ivory fragments identified thus far using ZooMS are therefore elephant ivory, despite the presence of hippopotamus skeletal remains at all three sites.

\section{Carbon Isotopes}

Three fragments of clearly identifiable non-artefactual hippopotamus teeth from Ndondondwane and one from Wosi yielded $\delta^{13} \mathrm{C}$ values between -12 and $-9 \%$. These indicate consumption of substantial quantities of $\mathrm{C}_{4}$ grasses and are significantly more positive than the $\delta^{13} \mathrm{C}$ of the rest of the ivory analysed (Fig. 10). In the late first millennium $\mathrm{AD}$ Thukela Valley, hippopotamus clearly grazed to a much greater extent than elephants. $\delta^{13} \mathrm{C}$ values of 39 ivory samples from KwaGandaganda ranged from -22.5 to $-16.2 \%$, with a mean of $-19.7 \pm 1.5 \%$. Most of our material from KwaGandaganda derives from Square 25, which dates to the Msuluzi phase of the Early Iron Age. $\delta^{13} \mathrm{C}$ values of the six specimens from areas other than Square 25 tend to cluster at the negative end of the range. This might be taken to hint at changes in ivory source areas over time, but we wish to be cautious in our interpretation of this small sample. $\delta^{13} \mathrm{C}$ values of 28 ivory samples from the site of Ndondondwane ranged from -22.6 to $-18.6 \%$, with a mean of $-20.5 \pm 0.8 \%$ o, and 15 from Wosi ranged from -21.2 to $-15.2 \%$, with a mean of $-18.3 \pm 1.6 \%$. The distributions of values from each pair of sites is significantly different (Mann-
Whitney $Z$-value for KwaGandaganda vs. Ndondondwane is 2.79, for KwaGandaganda vs. Wosi 2.65, for Ndondondwane vs. Wosi 3.96, $p<0.01$ in each case). As can be seen from Fig. 10, values for Wosi tend to be ${ }^{13} \mathrm{C}$ enriched compared with the other two sites, indicating that these animals consumed more grass. Samples from two historic elephants, on display in the KwaZulu-Natal Museum, fall in the middle of the range of archaeological samples, with $\delta^{13} \mathrm{C}$ values of -20.3 and $-20.8 \%$, respectively. One, the skeleton of a bull of 55 years, lived on the Mfolozi flats in the Mtubatuba area, inland of the St. Lucia estuary (no known museum accession number). He was illegally shot and killed in 1916. The other, a single, heavily weathered tusk, was found buried in the bank of the Dorpspruit in Pietermaritzburg in about 1880 (museum accession number 542).

Although there is a wide range of $\delta^{13} \mathrm{C}$ values, the median of those from KwaGandaganda and Ndondondwane is $-20.3 \%$ o. This is close to the value expected for purely $\mathrm{C}_{3}$ diets, when adjusted for depletion of $\delta^{13} \mathrm{C}$ in atmospheric carbon dioxide due to the burning of fossil fuels (see caption to Fig. 10). Many of these elephants, therefore, ate largely or entirely $\mathrm{C}_{3}$ diets and did not consume $\mathrm{C}_{4}$ grasses. These animals must have lived in forested or dense bushy habitats.

The fact that the $\delta^{13} \mathrm{C}$ values of hippopotamus are so much more positive than those of elephants, and clearly distinguishable from them, is consistent with the results of the ZooMS analyses. All of the waste ivory fragments in this study from all three sites derive from elephants and not hippopotami. Warthog would also have very positive $\delta^{13} \mathrm{C}$, so are clearly not represented here.

\section{Nitrogen Isotopes}

$\delta^{15} \mathrm{~N}$ values of 39 ivory samples from KwaGandaganda ranged from 6.9 to $14.3 \%$, with a mean of $9.1 \pm 1.7 \%$. Those from Ndondondwane ranged from 6.1 to $12.2 \%$, with a mean of $8.9 \pm 1.8 \%$ o $(n=28)$, and 15 samples from Wosi ranged from 7.9 to $13.1 \%$, with a mean of $10.8 \pm 1.9 \%$. The distributions of $\delta^{15} \mathrm{~N}$ values from KwaGandaganda and Ndondondwane are not significantly different (Mann-Whitney $Z$-value is 0.72 , $p=0.47$ ), but both are significantly different from Wosi (Mann-Whitney $Z$-value for KwaGandaganda vs. Wosi 2.85, for Ndondondwane vs. Wosi 3.11, $p<0.01$ for both). $\delta^{15} \mathrm{~N}$ values for Wosi tend to be slightly more positive compared with the other two sites. In this data set, higher $\delta^{15} \mathrm{~N}$ values are much more characteristic of 


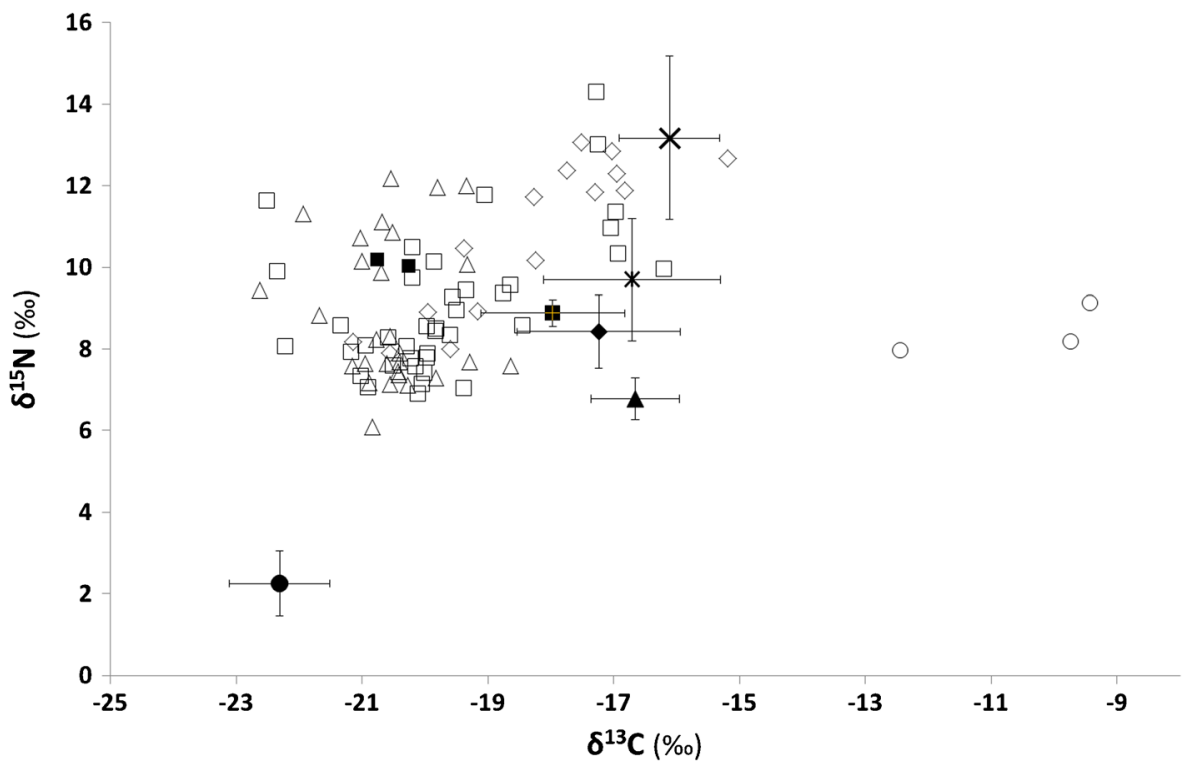

Fig. $10 \delta^{13} \mathrm{C}$ and $\delta^{15} \mathrm{~N}$ values for archaeological ivory from KwaZulu-Natal compared with reference samples from southern African wildlife parks. Samples from KwaGandaganda are shown as open squares, Ndondondwane as open triangles, Wosi as open diamonds and non-artefactual hippopotamus ivory from Ndondondwane and Wosi as open circles. Reference samples include two KwaZulu-Natal Museum historic elephants shown as filled squares and modern elephants plotted as means \pm one standard deviation. Ivory from Addo (South Africa) identified as larger bold X (van der Merwe et al. 1990; Vogel et al. 1990)

more positive $\delta^{13} \mathrm{C}$ values, as expected if these animals came from drier, savanna-type environments. The two historic KwaZulu-Natal elephants fall in the middle of the range of archaeological samples, with $\delta^{15} \mathrm{~N}$ values of $10.0 \%$ or the 1916 bull and $10.2 \%$ for the 1880 weathered tusk, respectively. $\delta^{13} \mathrm{C}$ and $\delta^{15} \mathrm{~N}$ in elephant ivory reflect the vegetation the elephant consumed, as well as the climate in which it grew, meaning these two isotope systems are indicative (although not definitive) of the habitat in which the elephant lived. The range of isotope values documented here is large enough to conclude that this ivory came from different environments and was not all from local elephant populations. Some ivory almost certainly did come from local elephants - samples with the most negative $\delta^{13} \mathrm{C}$ and low $\delta^{15} \mathrm{~N}$ values derived from relatively moist environments with dense forest/bush vegetation, like that of the KwaZulu-Natal river valleys at the time. They may also have come from forests on higher ground, such as the Qudeni and Nkandla forests about 20-30 km north of Ndondondwane, and from dense coastal bush or forest.
( $n=14)$, Botswana as smaller $X$ (van der Merwe et al. 1990) $(n=7)$, Tembe (South Africa) as filled square with cross (van der Merwe et al. 1990) $(n=6)$, Kruger (South Africa) as filled diamond (Codron et al. 2012; van der Merwe et al. 1990; Vogel et al. 1990) $(n=44)$, Zambia as filled triangle (van der Merwe et al. 1990) ( $n=4)$ and Knysna (South Africa) as filled circle (van der Merwe et al. 1990; Vogel et al. 1990) $(n=5) .1 .5 \%$ o has been added to $\delta^{13} \mathrm{C}$ values of modern elephants to correct for depletion of ${ }^{13} \mathrm{C}$ in atmospheric $\mathrm{CO}_{2}$ since the Industrial Revolution, due to burning of fossil fuels (Francey et al. 1999)

Other ivory, particularly that with more positive $\delta^{13} \mathrm{C}$ and higher $\delta^{15} \mathrm{~N}$ values, derived from more open grassy regions.

\section{Strontium Isotopes}

The four samples that were subjected to the leaching experiment included two from Ndondondwane (UCT $14431 / \mathrm{KZN} 38$ and $14423 / \mathrm{KZN} 30$ ), one from KwaGandaganda (UCT 17470/KZN 80) and one from Wosi (UCT 17509/KZN 119). None of the samples showed a consistent pattern of alteration in ${ }^{87} \mathrm{Sr} /{ }^{86} \mathrm{Sr}$ through the leaching profile (see Online Resource 2). The first three samples showed only very slight variation in ${ }^{87} \mathrm{Sr} /{ }^{86} \mathrm{Sr}$ through the profiles, with ranges from 0.00009 to 0.00042 . KwaGandaganda (UCT 17470) yielded a more variable profile, with a range of 0.00174 . Given the wide range of local variation in ${ }^{87} \mathrm{Sr} /{ }^{86} \mathrm{Sr}$ mentioned above, differences in the fourth decimal place do not significantly affect the interpretation of the results presented here. It appears that the influence of diagenetic strontium is minimal. Sample 
UCT 14423/KZN 30 from Ndondondwane was analysed by both laser and solution chemistry, yielding ${ }^{87} \mathrm{Sr} /{ }^{86} \mathrm{Sr}$ of $0.7126 \pm 0.0003$ and $0.71289 \pm 0.00002$, respectively. We therefore consider laser and solution measurements to be equivalent.

${ }^{87} \mathrm{Sr} /{ }^{86} \mathrm{Sr}$ of five samples of ivory from KwaGandaganda range from 0.71498 to 0.71626 , eight from Ndondondwane from 0.71255 to 0.71497 and the single value from Wosi is 0.71289 . The range of values from Ndondondwane/Wosi falls within the ranges of both the modern Achatina shells and the archaeological cattle teeth from those sites analysed by Arnold et al. (2013). We note, however, that range of ${ }^{87} \mathrm{Sr} /{ }^{86} \mathrm{Sr}$ from KwaGandaganda does not overlap with that from Ndondondwane and Wosi. This supports our statement above, based on light isotope analyses, that ivory brought to the three sites came from different catchments.

\section{Discussion}

In Fig. 10, we compare $\delta^{13} \mathrm{C}$ and $\delta^{15} \mathrm{~N}$ of archaeological ivory from KwaZulu-Natal with ivory from modern elephants from wildlife reserves in South Africa, Botswana and Zambia. Unfortunately, these include only a restricted range of habitats; in the past, elephants were much more common and widespread. Historical accounts describe an increase in elephant hunting for ivory exports when the first colonial settlement was established at Port Natal (now Durban) in 1824 (Carruthers et al. 2008). Records from the mid-nineteenth century describe elephants roaming near the Mfolozi River (Klingelhoeffer 1987). We recognise that the restricted distribution of our modern reference ivory samples is a limitation, but we use them as best we can to characterise elephant habitats and help interpret the measurements of archaeological ivory.

The range of $\delta^{13} \mathrm{C}$ values in archaeological ivory analysed in this study is large ( -22.6 to $-15.2 \%$ ). It extends from values seen in densely forested $\mathrm{C}_{3}$ environments (such as Knysna) to much more open grassland savannas (such as Kruger National Park, Tembe Elephant Park). The range of $\delta^{15} \mathrm{~N}$ values is also large. Our 39 ivory specimens from KwaGandaganda alone show a range of $7.4 \%$, compared with $6.5 \%$ for modern Kruger National Park elephants - the largest range from a single region in the modern data set. The Kruger Park is $19,485 \mathrm{~km}^{2}$ in extent, and encompasses several different vegetation types and rainfall zones, from 400 to $700 \mathrm{~mm}$ per annum. Thus, while it is currently not possible to reconstruct exactly where the ivory at Ndondondwane, KwaGandaganda and Wosi originated, we are confident that it was drawn from different elephant habitats. The most negative $\delta^{13} \mathrm{C}$ values identify elephants that lived in forested or bushy environments, with little grass. Some elephants from KwaGandaganda may have come from the densely vegetated coastal belt, which was probably moister than the environs of Wosi because of its proximity to the warm Indian Ocean (Whitelaw and Moon 1996, p. 70). Values towards the positive end of the range indicate that the animals consumed substantial quantities of $\mathrm{C}_{4}$ grasses. These likely included some drier areas, given that some of the $\delta^{15} \mathrm{~N}$ values are similar to those seen in elephants from more arid environments such as Addo National Park, where average annual rainfall is less than $445 \mathrm{~mm}$. It is important to note that the isotope values reflect diets averaged over several years, so the differences we see indicate substantial differences in elephant diet and environment. There may also be some chronological variation: Msuluzi phase ivory from KwaGandaganda and Wosi probably predates the wetter interval c. AD 750-1000 recorded at Lake Sibaya (Stager et al. 2013), while Ndondondwane phase material derives from this period. $\delta^{13} \mathrm{C}$ of the small number of Ndondondwane phase ivory fragments analysed from KwaGandaganda cluster towards the more negative end of the range recorded at that site.

We need to bear in mind that the number of samples analysed here is limited, but nevertheless, the fact that there are statistically significant differences in $\delta^{13} \mathrm{C}$ and $\delta^{15} \mathrm{~N}$ at the three sites is intriguing. It may be that there was some partitioning of the landscape in terms of ivory sourcing even at this early stage. Wosi and Ndondondwane, for instance, are only $1.3 \mathrm{~km}$ apart, though they are separated by the Thukela River. The results suggest that the river possibly functioned as a political boundary and thus points to an organisation of ivory procurement based on political territories or chiefdoms. We cannot, unfortunately, draw any conclusions about shifts in the area of ivory catchment over time. Material from Square 25 at KwaGandaganda shows highly varied $\delta^{13} \mathrm{C}$ and $\delta^{15} \mathrm{~N}$, clearly indicating ivory of heterogeneous origins even in the Msuluzi phase. Given the inter-site differences already mentioned, one would have to compare earlier and later assemblages from the same site to investigate possible shifts in catchment areas through time. We have insufficient data to do this.

Whether Early Iron Age people hunted elephants in more distant areas themselves or whether they obtained 
ivory through trade, as part of a network that also involved other goods, is unknown. As mentioned above, all three sites preserve evidence of contact with other parts of southern Africa (copper, ostrich eggshell, marine shell), although Early Iron Age communities lived settled lives, sometimes (as at KwaGandaganda) continuing to maintain and rebuild villages in the same locality over several centuries (Whitelaw 1994). These sites may have been more involved than previously recognised in trade networks. The possible scope and extent of these networks are discussed further below. This raises interesting and important questions about the role that trade may have played in the development of larger-scale economic and political organisation.

If a well-developed system of ivory procurement and processing existed from the seventh century onwards, what was this ivory for? Was it for the local market, and/ or was it being fed into more widespread distribution networks? We cannot answer this question definitively, but there are a number of lines of evidence that, in our opinion, suggest that both applied.

There is no doubt that in historical times in Africa, elephants - and by association, ivory — were imbued with powerful symbolic qualities. In west, east and central Africa, elephants were a potent origin symbol (Cosentino 1992). They were considered female in character, reflecting their matriarch-led herds. In this sense, elephants resemble origin pools, while tusks, seemingly analogous to reeds in origin pools (Whitelaw 2015, p. 14), can stand for a ruler's authority and virility. Elephants can take on human form, while humans can become elephants on death. In southern Africa, elephants can represent the authority and power of the Zulu king. His queen, like the Swazi queen mother, is called She Elephant. The Swazi king is Ngwenyama (Lion), but early on the main day of the big incwala, the annual Swazi ritual of kingship, he walks before his people wearing only an ivory penis cover. The people praise him: "You of the Elephant" and "Elephant of the Ngwane [i.e., of the Swazi]" (Kuper 1973, p. 622). Amongst other things, the performance presents the king as the fount of the life force of the nation. This connection between elephants and royalty seems an elaboration of a more general relationship because even among ordinary people, the spirit of a deceased homestead head can appear as an elephant (Raum 1973, p. 435). Indeed, Zulu ethnography indicates that elephants were believed to so resemble humans that young people avoided eating the flesh, for young women feared that they would give birth to one (Krige 1962, p. 388).
In historical times, elephant hunting for the ivory trade is well documented (e.g., Carruthers et al. 2008). Tusks moved upwards in hierarchical exchange systems that were genealogical in character (son $>$ father $>$ (chief) $>$ ancestors) and in return came the means to produce and procreate (semen, rain, cattle) (Hunter 1936, p. 387; Bryant 1967, p. 686; Kuper 1982, p. 17). The association of elephants with power and procreation, and the widespread distribution of an essentially common elephant symbolism in Africa, hints that these beliefs are likely to be of considerable antiquity. If so, ivory may have been valued in Early Iron Age farming communities in KwaZulu-Natal in the same way as in later centuries. Perhaps there is a connection here with the apparent preference for elephant ivory, rather than that from hippopotami or other species, found in this study.

Some manufactured ivory items, such as the toothshaped object from KwaGandaganda shown in Fig. 4, were very likely intended for local use. This is an ivory version of an artefact type also found in other materials (pierced canine teeth, copies of such teeth in bone) at this site and at Ndondondwane. It therefore fits well with the overall material culture assemblages of the time.

Ivory bangles or armlets were the largest, most frequent and most standardised type of artefact manufactured from ivory, and they occur not only at the KwaZulu-Natal sites but also at later sites in the Limpopo Valley such as Schroda, Pont Drift and K2 (Hanisch 1980; Raath 2014; Voigt 1983), and sites in Botswana such as Mosu and Kaitshàa (Denbow et al. 2015; Reid and Segobye 2000). Much of the ivory working waste recovered (in very substantial quantities) from Ndondondwane, KwaGandaganda and Wosi likely relates to the shaping of these bangles. This point may be relevant to our identification of all the ivory in this study as elephant - the shapes and sizes of hippopotamus and warthog tusks are unsuitable for making bangles like these. Abundant working waste suggests craft specialisation at Ndondondwane, KwaGandaganda and Wosi, as other Early Iron Age sites in KwaZulu-Natal, by contrast, yield no evidence of ivory working and few, if any, ivory artefacts. At present, we do not know what role (if any) ivory armlets may have played in local society. None of the Early Iron Age burials from KwaZulu-Natal include bangles, although this picture may change with further finds. Further to the north and several centuries later, two children at $\mathrm{K} 2$ and a male skeleton from Happy Rest were interred wearing ivory bangles (Steyn and Nienaber 2000; Voigt and Plug 1984). Detailed consideration of the ivory from sites in the Limpopo River 
Valley is beyond the scope of this paper. Nevertheless, we note that ivory from the tenth-twelfth century sites in the Limpopo region has long been assumed to be part of the range of goods exported in the Indian Ocean trade, either in raw or manufactured form (Forssman et al. 2014; Hall 1987; Huffman 2007; Maggs 1984a).

In the late first millennium $\mathrm{AD}$, we see evidence for exotic goods being imported into KwaZulu-Natal. Some came from other parts of South Africa (ostrich eggshell beads, probably also copper items), but a few were traded across the Indian Ocean: glass beads found at KwaGandaganda (Whitelaw 1994) and Ntshekane (Maggs and Michael 1976) and the glazed ceramic sherd from KwaGandaganda (Miller and Whitelaw 1994). There are very few of these, but given that they must have been rarities when first obtained, that only a small proportion of objects find their way into the archaeological record, and that excavations sample only limited areas of archaeological sites, this is not surprising. We do not, as yet, have foreign imports from Msuluzi phase occupations, but that may well be a sampling issue. What did communities in KwaZulu-Natal offer in exchange? Ivory is one possibility.

We note that trading for ivory on the East African coast was well established by the early first millennium $\mathrm{AD}$. The Periplus of the Erythraean Sea, probably written at Alexandria c. $\mathrm{AD} 100$, mentioned large quantities of ivory obtained from the East African coast (Casson 1989). Kwale people, expanding southwards into Mozambique and South Africa in the first few centuries $\mathrm{AD}$, may well have known about the ivory trade or even participated in it from their East African homeland.

In the ninth century, the Chinese writer Tuan Ch'engShih cites the East African coast as a source of ivory, ambergris and slaves. The early tenth-century traveller al-Mas'udi described ivory exported from East Africa to Oman and thence to India and China for making dagger handles, chess pieces and likely also bangles for Hindu brides (Freeman-Grenville 1962, pp. 14-16). Documentary evidence attests to this in the eighteenth century, as more than half of the ivory imported into India at that time was used for wedding bangles, as soft African savanna elephant ivory was valued over their own local ivory (Freeman-Grenville 1988, p. 11).

Trans-Indian Ocean voyaging may be far more ancient than any documentary records, if bananas had indeed reached Uganda by the fourth millennium BC (Lejju et al. 2006). A variety of other food crops were dispersed across the Indian Ocean in succeeding millennia, with African domesticates reaching India by at least 2000-1700 BC
(Boivin et al. 2013, 2014). This commerce relied on suitable winds and ocean currents, and it has long been thought that vessels relying on trade winds to cross the Indian Ocean probably did not make landfall on the African mainland further south than the northern end of the Mozambique Channel; winds and currents in this channel are challenging for sailors even today. Wood (2011) has shown that during the late first millennium $\mathrm{AD}$, imports into south-eastern Africa included beads likely made east of the Euphrates River and traded through the Persian Gulf. Many of these imported beads have been found at the trading depot of Chibuene (near modern Vilanculos), close to the southern end of the Mozambique Channel (Fig. 1). This was a very active trading depot in the late first millennium (Sinclair et al. 2012; Wood et al. 2012); indeed, at that time, glass beads were imported in larger numbers into southern Africa than into eastern Africa (Wood 2011; Wood et al. 2016). The eighth- to midtenth century Zhizo series is the best known of these beads, but Wood recently identified a "Chibuene series" that possibly predates the Zhizo beads (although the low numbers of Chibuene beads might relate to colour and "feel" preferences, with people in the interior preferring Zhizo beads). Chibuene and Zhizo series beads were traded inland to Kaitshàa and as far as Nqoma in north-western Botswana (Fig. 1) (Denbow et al. 2015; Wood 2011; Wood et al. 2012), a distance of approximately $1,500 \mathrm{~km}$ as the crow flies (and almost 1.5 times the distance from KwaGandaganda to Chibuene). Zhizo series beads have been identified from a number of areas in southern Africa, including, in Zimbabwe, Makuru, Leopard's Kopje Main Kraal, Zhizo Hill, Matsheumhlope and Three-Mile-Water (Wood 2005, p. 41). Beads that may belong to the Zhizo series also occur in a number of other assemblages from Zimbabwe and Botswana. Since the earliest trade in beads overlaps with at least part of the Msuluzi phase, some KwaZulu-Natal ivory may have been destined for a trading post such as Chibuene, then shipped onwards to more distant markets.

\section{Conclusions}

Stable carbon and nitrogen isotope analysis, in combination with species identification using ZooMS, shows that all of the ivory artefacts and fragments of worked ivory that we studied are elephant, rather than hippopotamus or warthog ivory. The elephants were drawn from 
a wide catchment that included both heavily bushed/ forested habitats and more open environments with abundant $\mathrm{C}_{4}$ grasses. Inferences from strontium isotope analysis are imprecise, given high regional variation in ${ }^{87} \mathrm{Sr} /{ }^{86} \mathrm{Sr}$, but are consistent with ivory at KwaGandaganda coming from different areas from ivory at Ndondondwane and Wosi. The principal manufactured items were large bangles or armlets. Production of these appears to be confined to a limited number of settlements, where it continued over several hundred years. These sites may have been politically and economically more important than others.

The abundant evidence of ivory working at KwaGandaganda, Wosi and Ndondondwane dates from the seventh-tenth centuries $\mathrm{AD}$, several hundred years earlier than the better-known evidence from the Limpopo River Valley. There, ivory is widely considered to be part of the goods exported through Indian Ocean trade. We suggest that at least some of the ivory from the KwaZulu-Natal sites may also have been destined for trans-oceanic trade based on (1) large quantities of ivory on some KwaZulu-Natal sites and (2) the new evidence reported here that ivory procurement was not merely local but was conducted over considerable distances, with a greater degree of organisation than previously suspected. Ivory export at this time would be consistent with the growing body of evidence for imported glass beads and other goods that increasingly indicate trade activity in the first millennium AD. KwaGandaganda, Wosi and Ndondondwane preserve the earliest evidence for large-scale ivory processing in southern Africa, the precursor of a larger, more expansive network of goods - including gold - that would flow through this region in the centuries to come.

Acknowledgments Permission to examine and sample the material was given by the heritage body Amafa KwaZulu-Natal under permit number $13 / 05$. We are extremely grateful to staff at the KwaZulu-Natal Museum, especially Carolyn Thorp and Mudzunga Munzhedzi for facilitating access to the collections in their care. Staff at Amafa KwaZulu-Natal including Annie van de Venter Radford, Hester Roodt, Derrick Mhlongo and Pholoso More helped AC access their collections. Peter Taylor, former curator at the Durban Natural Science Museum, provided rodent specimens for strontium isotope analysis. John Lanham and Ian Newton assisted with stable isotope analysis, and Kerryn Gray and Fayrooza Rawoot with strontium isotope analysis. The BioArCh team at York including Krista McGrath and Luke Spindler helped with the ZooMS analysis and Matthew Collins provided guidance and comments on the manuscript as a fellow investigator on our TEMBo project. Neil Rusch compiled the composite photographic image in Fig. 4. Tim Maggs guided this research, made many suggestions, answered innumerable questions and read and commented on a draft manuscript.

This research was funded from the European Union's Seventh Framework Programme (FP7/2007-2013) under grant agreement PIOF-GA-2012-332165, "TEMBo". In the early stages of the work, AC was further supported by the Claude Leon Foundation as a Postdoctoral Fellow. Additional funding came from the South African Research Chairs Initiative of the Department of Science and Technology and the National Research Foundation of South Africa. Findings and opinions expressed in this paper are those of the authors, and the funders do not accept any liability in this regard.

\section{Compliance with Ethical Standards}

Funding AC was funded by the European Union's Seventh Framework Programme (FP7/2007-2013) as a Marie Curie International Outgoing Fellow under grant agreement PIOF-GA-2012332165, "TEMBo". AC was funded as a Postdoctoral Fellow by the Claude Leon Foundation. JS was funded from the South African Research Chairs Initiative of the Department of Science and Technology and the National Research Foundation of South Africa.

Conflict of Interest The authors declare that they have no conflict of interest.

Open Access This article is distributed under the terms of the Creative Commons Attribution 4.0 International License (http:// creativecommons.org/licenses/by/4.0/), which permits unrestricted use, distribution, and reproduction in any medium, provided you give appropriate credit to the original author(s) and the source, provide a link to the Creative Commons license, and indicate if changes were made.

\section{References}

Ambrose, S. H. (1990). Preparation and characterization of bone and tooth collagen for isotopic analysis. Journal of Archaeological Science, 17(4), 431-451.

Ambrose, S. H. (1991). Effects of diet, climate and physiology on nitrogen isotope abundances in terrestrial foodwebs. Journal of Archaeological Science, 18(3), 293-317.

Ambrose, S. H., \& DeNiro, M. J. (1986). The isotopic ecology of East African mammals. Oecologia, 69(3), 395-406.

Amundson, R., Austin, A. T., Schuur, E. A. G., Yoo, K., Matzek, V., Kendall, C., Uebersax, D., Brenner, D., \& Baisden, W. T. (2003). Global patterns of the isotopic composition of soil and plant nitrogen. Global Biogeochemical Cycles, 17(1). doi:10.1029/2002GB001903.

Aranibar, J. N., Otter, L., Macko, S. A., Feral, C. J. W., Epstein, H. E., Dowty, P. R., Eckardt, F., Shugart, H. H., \& Swap, R. J. (2004). Nitrogen cycling in the soil-plant system along a precipitation gradient in the Kalahari sands. Global Change Biology, 10(3), 359-373.

Arnold, E. R., Greenfield, H. J., \& Creaser, R. A. (2013). Domestic cattle mobility in early farming villages in southern Africa: Harvest profiles and strontium $\left({ }^{87} \mathrm{Sr} /{ }^{86} \mathrm{Sr}\right)$ isotope analyses 
from Early Iron Age sites in the lower Thukela River Valley of South Africa. Archaeological and Anthropological Sciences, 5(2), 129-144.

Balfour, D., Dublin, H. T., Fennessy, J., Gibson, D., Niskanen, L., \& Whyte, I. J. (2007). Review of options for managing the impacts of locally overabundant African elephants. Gland: The World Conservation Union (IUCN).

Beukes, C. F. (2000). KwaGandaganda: An archaeozoological case study of the exploitation of animal resources during the Early Iron Age in KwaZulu-Natal. MA thesis, University of South Africa.

Boivin, N., Crowther, A., Helm, R., \& Fuller, D. Q. (2013). East Africa and Madagascar in the Indian Ocean world. Journal of World Prehistory, 26(3), 213-281.

Boivin, N., Crowther, A., Prendergast, M., \& Fuller, D. Q. (2014). Indian Ocean food globalisation and Africa. African Archaeological Review, 31(4), 547-581.

Botha, M. S., \& Stock, W. D. (2005). Stable isotope composition of faeces as an indicator of seasonal diet selection in wild herbivores in southern Africa. South African Journal of Science, 101(August), 371-374.

Bryant, A. T. (1967). The Zulu people as they were before the white man came (2nd ed.). Pietermaritzburg: Shuter and Shooter.

Buckley, M., \& Collins, M. J. (2011). Collagen survival and its use for species identification in Holocene-lower Pleistocene bone fragments from British archaeological and paleontological sites. Antiqua, 1(1), 1-7.

Buckley, M., Collins, M., Thomas-Oates, J., \& Wilson, J. C. (2009). Species identification by analysis of bone collagen using matrix-assisted laser desorption/ionisation time-offlight mass spectrometry. Rapid Communications in Mass Spectrometry, 23, 3843-3854.

Buckley, M., Kansa, S. W., Howard, S., Campbell, S., ThomasOates, J., \& Collins, M. (2010). Distinguishing between archaeological sheep and goat bones using a single collagen peptide. Journal of Archaeological Science, 37(1), 13-20.

Carruthers, J., Boshoff, A., Slotow, R., Biggs, H. C., Avery, G., \& Matthews, W. (2008). The elephant in South Africa: History and distribution. In R. J. Scholes \& K. G. Mennell (Eds.), Elephant management: A scientific assessment for South Africa (pp. 23-83). Johannesburg: Wits University Press.

Casson, L. (1989). The Periplus Maris Erythraei: Text with introduction, translation, and commentary. Princeton: Princeton University Press.

Cerling, T. E., Harris, J. M., MacFadden, B. J., Leakey, M. G., Quade, J., Eisenmann, V., \& Ehleringer, J. R. (1997). Global vegetation change through the Miocene/Pliocene boundary. Nature, 389(6647), 153-158.

Cerling, T. E., Omondi, P., \& Macharia, A. N. (2007). Diets of Kenyan elephants from stable isotopes and the origin of confiscated ivory in Kenya. African Journal of Ecology, 45(4), 614-623.

Cerling, T. E., Harris, J. M., Hart, J. A., Kaleme, P., Klingel, H., Leakey, M. G., Levin, N. E., Lewison, R. L., \& Passey, B. H. (2008). Stable isotope ecology of the common hippopotamus. Journal of Zoology, 276(2), 204-212.
Cerling, T. E., Wittemyer, G., Ehleringer, J. R., Remien, C. H., \& Douglas-Hamilton, I. (2009). History of Animals using Isotope Records (HAIR): A 6-year dietary history of one family of African elephants. Proceedings of the National Academy of Sciences of the United States of America, 106(20), 8093-8100.

Codron, D., Codron, J., Lee-Thorp, J. A., Sponheimer, M., De Ruiter, D., Sealy, J., Grant, R., \& Fourie, N. (2007). Diets of savanna ungulates from stable carbon isotope composition of faeces. Journal of Zoology, 273(1), 21-29.

Codron, J., Codron, D., Sponheimer, M., Kirkman, K., Duffy, K. J., Raubenheimer, E. J., Mélice, J. L., Grant, R., Clauss, M., \& Lee-Thorp, J. A. (2012). Stable isotope series from elephant ivory reveal lifetime histories of a true dietary generalist. Proceedings of the Royal Society of London B: Biological Sciences, 279(1737), 2433-2441.

Copeland, S. R., Sponheimer, M., le Roux, P. J., Grimes, V., LeeThorp, J. A., de Ruiter, D. J., \& Richards, M. P. (2008). Strontium isotope ratios $\left({ }^{87} \mathrm{Sr} /{ }^{86} \mathrm{Sr}\right)$ of tooth enamel: A comparison of solution and laser ablation multicollector inductively coupled plasma mass spectrometry methods. Rapid Communications in Mass Spectrometry, RCM, 22(20), 3187-3194.

Cosentino, D. J. (1992). The talking (gray) heads: Elephant as metaphor in African myth and folklore. In D. H. Ross (Ed.), Elephant. The animal and its ivory in African culture (pp. 8195). Los Angeles: University of California.

Coutu, A. N. (2011). Tracing the links between elephants, humans, and landscapes during the nineteenth-century East African ivory trade: A bioarchaeological study. $\mathrm{PhD}$ dissertation, University of York.

de Boer, W. F., van Langevelde, F., Prins, H. H. T., de Ruiter, P. C., Blanc, J., Vis, M. J. P., Gaston, K. J., \& Hamilton, I. D. (2013). Understanding spatial differences in African elephant densities and occurrence, a continent-wide analysis. Biological Conservation, 159, 468-476.

Denbow, J., Klehm, C., \& Dussubieux, L. (2015). The glass beads of Kaitshàa and early Indian Ocean trade into the far interior of southern Africa. Antiquity, 89(344), 361-377.

DeNiro, M. J. (1985). Postmortem preservation and alteration of in vivo bone collagen isotope ratios in relation to palaeodietary reconstruction. Nature, 317, 806-809.

Fiddyment, S., Holsinger, B., Ruzzier, C., Devine, A., Binois, A., Albarella, U., Fischer, R., Nichols, E., Curtis, A., Cheese, E., Teasdale, M. D., Checkley-Scott, C., Milner, S. J., Rudy, K. M., Johnson, E. J., Vnouček, J., Garrison, M., McGory, S., Bradley, D. G., \& Collins, M. J. (2015). Animal origin of 13th-century uterine vellum revealed using noninvasive peptide fingerprinting. Proceedings of the National Academy of Sciences, 112(49), 15066-15071.

Forssman, T., Page, B., \& Selier, S. A. J. (2014). How important was the presence of elephants as a determinant of the Zhizo settlement of the greater Mapungubwe landscape. Journal of African Archaeology, 12, 75-87.

Francey, R. J., Allison, C. E., Etheridge, D. M., Trudinger, C. M., Enting, I. G., Leuenberger, M., Langenfelds, R. L., Michel, E., \& Steele, L. P. (1999). A 1000-year high precision record of $\delta^{13} \mathrm{C}$ in atmospheric $\mathrm{CO}_{2}$. Tellus B, 51(2), 170-193. 
Fread, E. R. (2007). Taphonomy and subsistence strategies at Ndondondwane, a zooarchaeological perspective on an Early Iron Age homestead in the Thukela Valley, Republic of South Africa. MA thesis, University of Manitoba.

Freeman-Grenville, G. (1962). The East African coast: Select documents. Oxford: Clarendon Press.

Freeman-Grenville, G. (1988). The Swahili coast, 2nd to 19th centuries. London: Variorum.

GlobCover Land Cover v2 2008 database. (2008). European Space Agency, European Space Agency GlobCover Project, led by MEDIAS-France. (http://due.esrin.esa.int/page_ globcover.php) Accessed 1 Dec 2015.

Greenfield, H. J., \& van Schalkwyk, L. (2003). Intra-settlement social and economic organization of Early Iron Age farming communities in southern Africa: A view from Ndondondwane. Azania, 38(1), 121-137.

Hall, M. (1987). Archaeology and modes of production in precolonial southern Africa. Journal of Southern African Studies, 14(1), 1-17.

Hanisch, E. O. M. (1980). An archaeological interpretation of certain Iron Age sites in the Limpopo/Shashi valley. MA thesis, University of Pretoria.

Hanisch, E. O. M. (1981). Schroda: A Zhizo site in the northern Transvaal. In A. Voigt (Ed.), Guide to archaeological sites in the northern and eastern Transvaal (pp. 37-53). Pretoria: Transvaal Museum.

Heaton, T. H., Vogel, J. C., von La Chevallerie, G., \& Collett, G. (1986). Climatic influence on the isotopic composition of bone nitrogen. Nature, 322, 822-823.

Hodell, D. A., Quinn, R. L., Brenner, M., \& Kamenov, G. (2004). Spatial variation of strontium isotopes $\left({ }^{87} \mathrm{Sr} /{ }^{86} \mathrm{Sr}\right)$ in the Maya region: A tool for tracking ancient human migration. Journal of Archaeological Science, 31(5), 585-601.

Hollemeyer, K., Altmeyer, W., Heinzle, E., \& Pitra, C. (2012). Matrix-assisted laser desorption/ionization time-of-flight mass spectrometry combined with multidimensional scaling, binary hierarchical cluster tree and selected diagnostic masses improves species identification of Neolithic keratin sequences from furs of the Tyrolean Iceman Oetzi. Rapid Communications in Mass Spectrometry, 26(16), 1735-1745.

Huffman, T. N. (2007). Handbook to the Iron Age: The archaeology of pre-colonial farming societies in Southern Africa. Scottsville: University of KwaZulu-Natal Press.

Hunter, M. (1936). Reaction to conquest: Effects of contact with Europeans on the Pondo of South Africa. London: Oxford University Press.

Insoll, T. (1995). A cache of hippopotamus ivory at Gao, Mali. Antiquity, 69, 327-336.

Ishibashi, H., Takeuchi, T., Whyte, I., \& Koike, H. (1999). $\delta^{15} \mathrm{~N}$ and $\delta^{13} \mathrm{C}$ measurements from the African elephant, Loxodonta africana, used for ivory sourcing. Bulletin of the Graduate School of Social and Cultural Studies, Kyushu University, 5, 1-8.

Johnston, S. T., McCourt, S., Bisnath, A., \& Mitchell, A. A. (2002). The Tugela terrane, Natal belt: Kibaran magmatism and tectonism along the southeast margin of the Kaapvaal Craton. South African Journal of Geology, 105(1), 1-13.

Kirby, D., Buckley, M., \& Promise, E. (2013). Identification of collagen-based materials in cultural heritage. Analyst, 138(17), 4849-4858.
Klingelhoeffer, E. W. (1987). Aspects of the ecology of the elephant Loxodonta africana (Blumenbach, 1797), and a management plan for the Tembe Elephant Reserve in Tongaland, KwaZulu. PhD dissertation, University of Pretoria.

Kohn, M. J. (2010). Carbon isotope compositions of terrestrial $C_{3}$ plants as indicators of (paleo) ecology and (paleo) climate. Proceedings of the National Academy of Sciences, 107(46), 19691-19695.

Krige, E. J. (1962). The social system of the Zulus (4th ed.). Pietermaritzburg: Shuter \& Shooter.

Kuper, H. (1973). Costume and cosmology: The animal symbolism of the ncwala. Man, 8(4), 613-630.

Kuper, A. (1982). Wives for cattle: Bridewealth and marriage in southern Africa. London: Routledge \& Kegan Paul.

Le Roux, P. J., Lee-Thorp, J. A., Copeland, S. R., Sponheimer, M., \& de Ruiter, D. J. (2014). Strontium isotope analysis of curved tooth enamel surfaces by laser-ablation multi-collector ICP-MS. Palaeogeography, Palaeoclimatology, Palaeoecology, 416, 142-149.

Lee-Thorp, J. A., Sealy, J. C., \& Van Der Merwe, N. J. (1989). Stable carbon isotope ratio differences between bone collagen and bone apatite, and their relationship to diet. Journal of Archaeological Science, 16(6), 585-599.

Lejju, B. J., Robertshaw, P., \& Taylor, D. (2006). Africa's earliest bananas? Journal of Archaeological Science, 33(1), 102113.

Locke, M. (2008). Structure of ivory. Journal of Morphology, 269(4), 423-450.

Loubser, H. N. (1993). Ndondondwane: The significance of features and finds from a ninth-century site on the lower Thukela River, Natal. Natal Museum Journal of Humanities, 5, 109151.

Maggs, T. (1980). Mzonjani and the beginning of the Iron Age in Natal. Annals of the Natal Museum, 24(1), 71-96.

Maggs, T. (1984a). Iron age settlement and subsistence patterns in the Tugela river basin, Natal. In M. Hall, G. Avery, D. M. Avery, M. L. Wilson, \& A. J. B. Humphreys (Eds.), Frontiers: Southern African archaeology (pp. 194-206). Oxford: British Archaeological Reports, International Series 207.

Maggs, T. (1984b). Ndondondwane: A preliminary report on an Early Iron Age site on the lower Tugela River. Annals of the Natal Museum, 26(1), 71-93.

Maggs, T., \& Michael, M. A. (1976). Ntshekane: An Early Iron Age site in the Tugela Basin, Natal. Southern African Humanities, 22(3), 705-740.

Miller, D., \& Whitelaw, G. (1994). Early Iron Age metal working from the site of KwaGandaganda, Natal, South Africa. The South African Archaeological Bulletin, 49(160), 79-89.

Mucina, L., \& Rutherford, M. C. (2006). The vegetation of South Africa, Lesotho and Swaziland. Strelitzia 19. Pretoria: South African National Biodiversity Institute.

Murphy, B. P., \& Bowman, D. M. (2006). Kangaroo metabolism does not cause the relationship between bone collagen $\delta^{15} \mathrm{~N}$ and water availability. Functional Ecology, 20(6), 10621069.

Murphy, B. P., \& Bowman, D. M. (2009). The carbon and nitrogen isotope composition of Australian grasses in relation to climate. Functional Ecology, 23(6), 1040-1049.

O'Connell, T. C., \& Hedges, R. E. (1999). Investigations into the effect of diet on modern human hair isotopic values. 
American Journal of Physical Anthropology, 108(4), 409425.

O'Connell-Rodwell, C. E., Rodwell, T., Rice, M., \& Hart, L. A. (2000). Living with the modern conservation paradigm: Can agricultural communities co-exist with elephants? A fiveyear case study in East Caprivi, Namibia. Biological Conservation, 93(3), 381-391.

Phillipson, D. W. (1977). The later prehistory of eastern and southern Africa. London: Heinemann.

Pin, C., Briot, D., Bassin, C., \& Poitrasson, F. (1994). Concomitant separation of strontium and samariumneodymium for isotopic analysis in silicate samples, based on specific extraction chromatography. Analytica Chimica Acta, 298(2), 209-217.

Raath, A. (2014). An archaeological investigation of Zhizo/ Leokwe foodways at Schroda and Pont Drift, Limpopo Valley, South Africa. $\mathrm{PhD}$ thesis, Yale University.

Raubenheimer, E. J., Dauth, J., Dreyer, M. J., Smith, P. D., \& Turner, M. L. (1990). Structure and composition of ivory of the African elephant (Loxondonta africana). South African Journal of Science, 86, 192-193.

Raum, O. F. (1973). The social functions of avoidances and taboos among the Zulu. Berlin: Walter de Gruyter.

Reid, A., \& Segobye, A. K. (2000). An ivory cache from Botswana. Antiquity, 74(284), 326-331.

Russell, T., Silva, F., \& Steele, J. (2014). Modelling the spread of farming in the Bantu-speaking regions of Africa: An archaeology-based phylogeography. PloS One, 9(1), e87854.

Sealy, J. C., van der Merwe, N. J., Sillen, A., Kruger, F. J., \& Krueger, H. W. (1991). ${ }^{87} \mathrm{Sr} /{ }^{86} \mathrm{Sr}$ as a dietary indicator in modern and archaeological bone. Journal of Archaeological Science, 18(3), 399-416.

Shaw, M. (1974). Material culture. In W. D. Hammond-Tooke (Ed.), The Bantu-speaking peoples of Southern Africa (pp. 85-131). London: Routledge Kegan Paul.

Sillen, A., Hall, G., Richardson, S., \& Armstrong, R. (1998). ${ }^{87} \mathrm{Sr} /{ }^{86} \mathrm{Sr}$ ratios in modern and fossil food-webs of the Sterkfontein Valley: Implications for early hominid habitat preference. Geochimica et Cosmochimica Acta, 62(14), 2463-2473.

Sinclair, P., Ekblom, A., \& Wood, M. (2012). Trade and society on the south-east African coast in the later first millennium AD: The case of Chibuene. Antiquity, 86(333), 723.

Sitati, N. W., Walpole, M. J., \& Leader-Williams, N. (2005). Factors affecting susceptibility of farms to crop raiding by African elephants: Using a predictive model to mitigate conflict. Journal of Applied Ecology, 42(6), 1175-1182.

Skinner, J. D., \& Chimimba, C. T. (2005). The mammals of the southern African sub-region. Cambridge: Cambridge University Press.

Sponheimer, M., Lee-Thorp, J. A., DeRuiter, D. J., Smith, J. M., van der Merwe, N. J., Reed, K., Grant, C. C., Ayliffe, L. K., Robinson, T. F., Heidelberger, C., \& Marcus, W. (2003a). Diets of southern African Bovidae: Stable isotope evidence. Journal of Mammalogy, 84(2), 471-479.

Sponheimer, M., Robinson, T., Ayliffe, L., Roeder, B., Hammer, J., Passey, B., West, A., Cerling, T., Dearing, D., \& Ehleringer, J. (2003b). Nitrogen isotopes in mammalian herbivores: Hair $\delta^{15} \mathrm{~N}$ values from a controlled feeding study. International Journal of Osteoarchaeology, 13(1-2), 80-87.

Stager, J. C., Ryves, D. B., King, C., Madson, J., Hazzard, M., Neumann, F. H., \& Maud, R. (2013). Late Holocene precipitation variability in the summer rainfall region of South Africa. Quaternary Science Reviews, 67, 105-120.

Stewart, J. R., Allen, R. B., Jones, A. K., Kendall, T., Penkman, K. E. H., Demarchi, B., O'Connor, T., \& Collins, M. J. (2014). Walking on eggshells: A study of egg use in AngloScandinavian York based on eggshell identification using ZooMS. International Journal of Osteoarchaeology, 24(3), 247-255.

Steyn, M., \& Nienaber, W. C. (2000). Iron Age human skeletal remains from the Limpopo Valley and Soutpansberg area. Goodwin Series, 112-116.

Stone, M. L. (1972). Organized poaching in Kitui district: A failure in district authority, 1900 to 1960. The International Journal of African Historical Studies, 5(3), 436-452.

Tieszen, L. L., \& Imbamba, S. K. (1980). Photosynthetic systems, carbon isotope discrimination and herbivore selectivity in Kenya. African Journal of Ecology, 18(4), 237-242.

van der Merwe, N. J., Lee-Thorp, J. A., Thackeray, J. F., HallMartin, A., Kruger, F. J., Coetzee, H., Bell, R. H. V., \& Lindeque, M. (1990). Source-area determination of elephant ivory by isotopic analysis. Nature, 346(6286), 744-746.

van Doorn, N. L. (2014). Zooarchaeology by Mass Spectrometry (ZooMS). In C. Smith (Ed.), Encyclopedia of global archaeology (pp. 7998-8000). New York: Springer.

Van Klinken, G. J. (1999). Bone collagen quality indicators for palaeodietary and radiocarbon measurements. Journal of Archaeological Science, 26(6), 687-695.

van Schalkwyk, L. (1994). Wosi: An Early Iron Age village in the lower Thukela Basin, Natal. Natal Museum Journal of Humanities, 6, 65-117.

Vogel, J. C. (1978). Isotope assessment of the dietary habits of ungulates. South African Journal of Science, 74(August), 298-301.

Vogel, J. C., Eglington, B., \& Auret, J. M. (1990). Isotope fingerprints in elephant bone and ivory. Nature, 346, 747-749.

Voigt, E. A. (1983). Mapungubwe: An archaeozoological interpretation of an Iron Age community. Pretoria: Transvaal Museum.

Voigt, E. A. (1984). The faunal remains from Magogo and Mhlopeni: Small stock herding in the Early Iron Age of Natal. Annals of the Natal Museum, 26(1), 141-163.

Voigt, E. A., \& Peters, J. H. (1994). The faunal assemblage from Wosi in the Thukela Valley. Natal Museum Journal of Humanities, 6, 105-117.

Voigt, E. A., \& Plug, I. (1984). Happy Rest - the earliest Iron-Age fauna from the Soutpansberg. South African Journal of Science, 80(5), 221-227.

Voigt, E. A., \& von den Driesch, A. (1984). Preliminary report on the faunal assemblage from Ndondondwane, Natal. Annals of the Natal Museum, 26(1), 95-104.

von Holstein, I. C., Ashby, S. P., van Doorn, N. L., Sachs, S. M., Buckley, M., Meiri, M., \& Collins, M. J. (2014). Searching for Scandinavians in pre-Viking Scotland: Molecular fingerprinting of Early Medieval combs. Journal of Archaeological Science, 41, 1-6.

Whitelaw, G. (1994a). KwaGandaganda: settlement patterns in the Natal Early Iron Age. Southern African Humanities, 6, 1-64. 
Whitelaw, G. (1994b-95). Towards an Early Iron Age worldview: Some ideas from KwaZulu Natal. Azania: Archaeological Research in Africa, 29(1), 37-50.

Whitelaw, G. (2013). Pollution concepts and marriage for the southern African Iron Age. Cambridge Archaeological Journal, 23(2), 203-225.

Whitelaw, G. (2015). Economy and cosmology in the Iron Age of KwaZulu-Natal. PhD dissertation, University of the Witwatersrand.

Whitelaw, G., \& Moon, M. (1996). The ceramics and distribution of pioneer agriculturists in KwaZulu-Natal. Natal Museum Journal of Humanities, 8, 53-79.

Whitmore, G. P., Uken, R., \& Meth, D. L. (1999). KwaZulu-Natal: 3500 million years of geological history. In University of KwaZulu-Natal. Durban: Geology Education Museum (GEM).
Wood, M. (2005). Glass beads and pre-European trade in the Shashe-Limpopo region. In MA thesis. Witwatersrand: University of the.

Wood, M. (2011). Interconnections: Glass beads and trade in southern and eastern Africa and the Indian Ocean-7th to 16th centuries $A D$. Uppsala: Studies in Global Archaeology.

Wood, M., Dussubieux, L., \& Robertshaw, P. (2012). The glass of Chibuene, Mozambique: New insights into early Indian Ocean trade. South African Archaeological Bulletin, 67(195), 59-74.

Wood, M., Panighello, S., Orsega, E. F., Robertshaw, P., van Elteren, J. T., Crowther, A., Horton, M., \& Boivin, N. (2016). Zanzibar and Indian Ocean trade in the first millennium CE: The glass bead evidence. Archaeological and Anthropological Sciences. doi:10.1007/s12520-0150310-z. 